*ak RMIS View/Frint Document Cover Sheet tow

This document was retrieved from the Documentation and Records Manaqement (DRM) ISEARCH System. It is intended for Information only and may not be the most recent or updated version. Contact a Document Service Center (see Hanford Info for locations) if you need additional retrieval information.

Accession \#: D196082285

Document \#: SD-EN-EV-034

Title/Desc:

105DR LARGE SODIUM FIRE FACILITY CLOSURE ACTIVITIES EVALUATION REPORT

Pages: 85 
COMPLETE

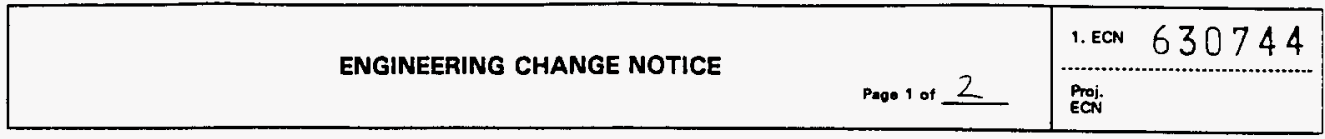

\begin{tabular}{|c|c|c|c|c|c|}
\hline \multirow{3}{*}{$\begin{array}{l}\text { 2. ECN Category } \\
\text { (mark one) } \\
\text { Supplemental } \\
\text { Direct Revision } \\
\text { Change ECN } \\
\text { Temporary } \\
\text { Standby } \\
\text { Supersedure } \\
\text { Cancel/Void } \\
4-22^{2}-96\end{array}$} & \multicolumn{2}{|c|}{$\begin{array}{l}\text { 3. Originator's Name, Organization, MSIN, } \\
\text { and Telephone No. } \\
\text { J. G. Adler, WHC/PSO/ES, H6-23, } \\
\text { 376-7513 }\end{array}$} & \multicolumn{2}{|c|}{$\begin{array}{l}\text { 3a. Uso Requíred? } \\
{[] \text { Yes }[\mathrm{x}] \text { No }}\end{array}$} & $\begin{array}{l}\text { 4. Date } \\
4 / 19 / 96\end{array}$ \\
\hline & \multicolumn{2}{|c|}{$\begin{array}{l}\text { 5. Project Title/No./Work order No. } \\
\text { 105-DR LARGE SODIUM FIRE } \\
\text { FACILITY CLOSURE ACTIVITIES } \\
\text { EVALUATION REPORT }\end{array}$} & \multicolumn{2}{|c|}{$\begin{array}{l}\text { 6. Bldg./Sys./Fac. No. } \\
\text { 105-DR LSFF }\end{array}$} & $\begin{array}{c}\text { 7. Approval Designator } \\
\text { E }\end{array}$ \\
\hline & \multicolumn{2}{|c|}{$\begin{array}{l}\text { 8. Document Numbers Changed by this ECN } \\
\text { (includes sheet no, and rev.) } \\
\text { WHC-SD-EN-EV-034, Rev } 0\end{array}$} & \multicolumn{2}{|c|}{$\begin{array}{l}\text { 9. Related ECN No(s). } \\
\qquad \mathrm{n} / \mathrm{a}\end{array}$} & $\begin{array}{l}\text { 10. Related PO No. } \\
\qquad \mathrm{n} / \mathrm{a}\end{array}$ \\
\hline \multirow{2}{*}{$\begin{array}{l}\text { 11a. Modification Work } \\
\text { [] Yes (fill out Blk. } \\
11 \mathrm{~b}) \\
{[\mathrm{X}] \text { No (NA Blks. 11b, }} \\
11 c, 11 \mathrm{~d})\end{array}$} & \multirow[t]{2}{*}{$\begin{array}{l}\text { 11b. Work Package } \\
\text { No. } \\
\text { n/a }\end{array}$} & \multirow{2}{*}{\multicolumn{2}{|c|}{$\begin{array}{l}\text { 11c. Modification Work Complete } \\
n / a\end{array}$}} & \multicolumn{2}{|c|}{$\begin{array}{l}\text { 11d. Restored to Original Condi- } \\
t \text { ion (Temp. or Standby ECN only) } \\
\mathrm{n} / \mathrm{a}\end{array}$} \\
\hline & & & & Cog. En & neer signature \& Date \\
\hline
\end{tabular}

12. Description of Change

Minor text revisions to the 105-DR LARGE SODIUM FIRE FACILITY CLOSURE ACTIVITIES

EVALUATION REPORT, WHC-SD-EN-EV-034. Correction of typographical errors and clarify text.

13a. Just ification (mark one)

Criteria Change [] Design Improvement As-Found [] Facilitate Const

[]
[]

Envirormental

Const. Error/Omission

[]

Facility Deactivation

Design Error/Omission

13b. Justification Details 


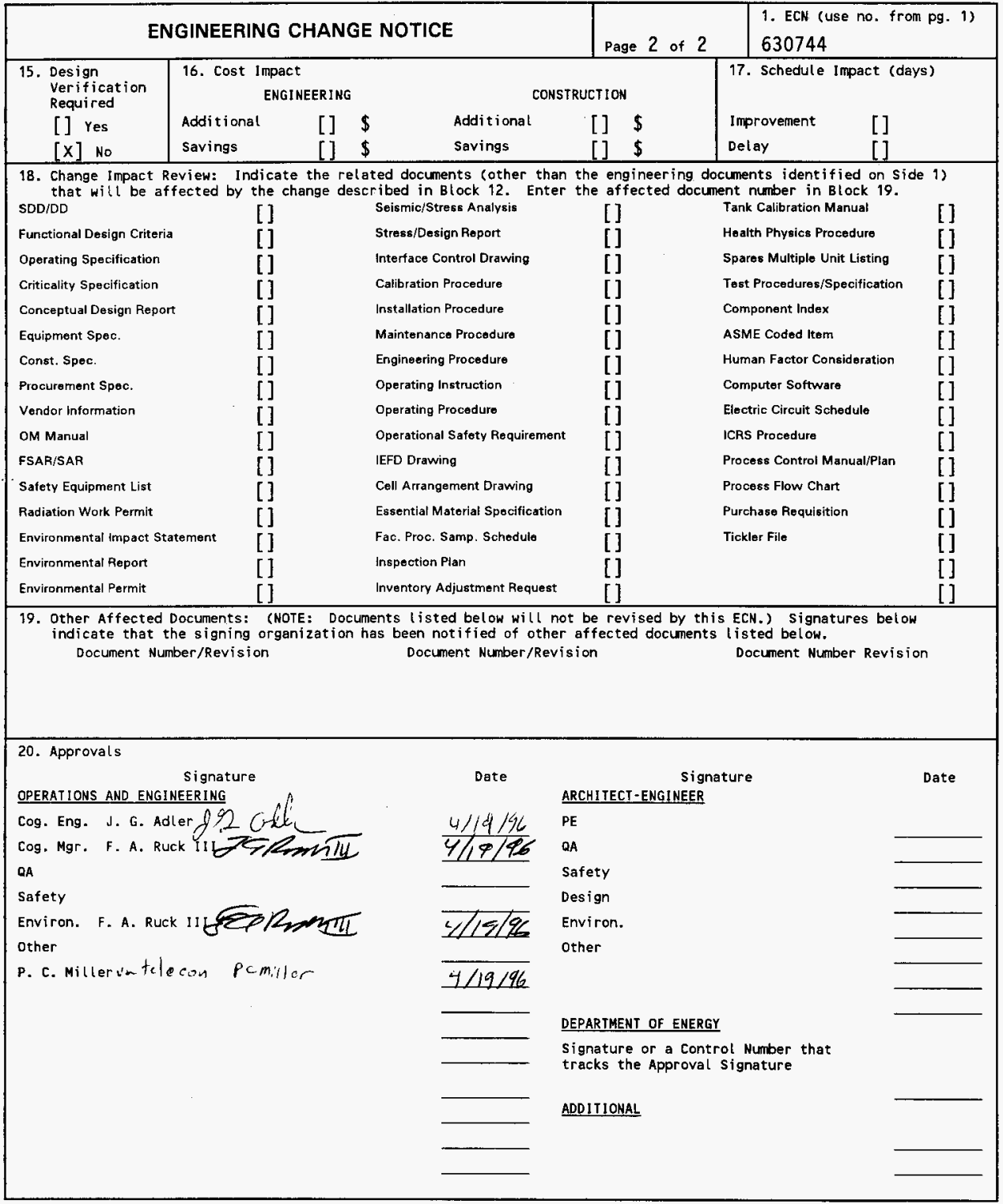




\title{
105-DR LARGE SODIUM FIRE FACILITY CLOSURE ACTIVITIES EVALUATION REPORT
}

\author{
J. G. Adler
}

West inghouse Hanford Co., Richland, WA 99352

U.S. Department of Energy Contract DE-AC06-87RL10930

$\begin{array}{lll}\text { EDT/ECN: } & 622835 & \text { UC: } 630 \\ \text { Org Code: } & 01821 & \text { Charge Code: } \\ \text { B\&R Code: } & \text { EX7003000 } & \text { Total Pages: } 83.84\end{array}$

Key Words: RCRA, closure, 105-DR, sodium, soil, sampling, analysis, data evaluation, data validation

Abstract: This report evaluates the closure activities at the 105-DR Large Sodium Fire Facility. The evaluation compares these activities to the regulatory requirements and closure $\mathrm{plan}$ requirements. The report concludes that the areas identified in the closure plan can be clean closed.

TRADEMARK DISCLAIMER. Reference herein to any specific comercial product, process, or service by trade name, trademark, manufacturer, or otherwise, does not necessarily constitute or imply its endorsement, recommendation, or favoring by the United states Government or any agency thereof or its contractors or subcontractors.

Printed in the United States of America. To obtain copies of this document, contact: WHC/BCS Document Control Services, P.O. Box 1970, Mailstop H6-08, Richland WA 99352, Phone (509) 372-2420; Fax (509) 376-4989.

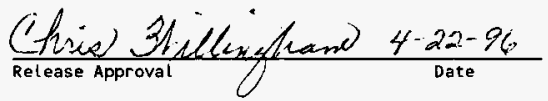

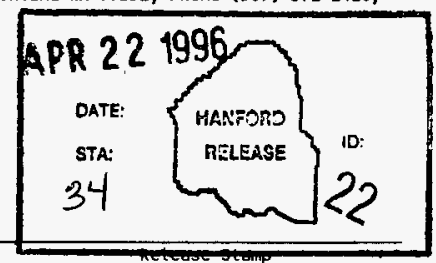

Approved for Public Release 
(2) Title

105-DR LARGE SODIUM FIRE FACILITY CLOSURE ACTIVITIES EVALUATION REPORT

CHANGE CONTROL RECORD

\begin{tabular}{|c|l|}
\hline (3) Revision & (4) Description of Change - Replace, Add, and Delete Pages \\
\hline 0 & (7) $\begin{array}{l}\text { Initial issue, EDT \#612839, Apri1 12, } \\
1996\end{array}$ \\
\hline 1 & $\begin{array}{l}\text { Correction of typographical errors and } \\
\text { minor comments for clarification of text. } \\
E C N \# 630744\end{array}$ \\
\hline$R$
\end{tabular}

\begin{tabular}{|c|c|}
\hline (5) Cog. Engr. & (6) Cog. Mor. Date \\
\hline$n / a$ & $\mathrm{n} / \mathrm{a}$ \\
\hline $\begin{array}{l}\text { ofede } \\
41221 \% 2\end{array}$ & 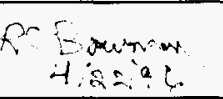 \\
\hline
\end{tabular}




\section{5-DR Large Sodium Fire Facility Closure Activities Evaluation Report}

Prepared for the U.S. Department of Energy Office of Environmental Restoration and Waste Management

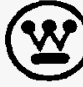


WHC-SD-EN-EV-034, Rev. 1

1

\section{5-DR LARGE SODIUH FIRE FACILITY CLOSURE ACTIVITIES EVALUATION REPORT}

\section{EXECUTIVE SUMMARY}

This report summarizes and evaluates the closure activities conducted at the 105-DR Large Sodium Fire Facility. The evaluation assesses the dangerous waste contamination for the purpose of partially clean closing the 105-DR Large Sodium Fire Facility as described in the 105-DR Large Sodium Fire Facility Closure Plan, DOE/RL-90-25 (DOE-RL 1995a).

The introduction outlines the regulatory background, provides general information about the 105-DR Large Sodium Fire Facility, and outlines the closure strategy. The next sections specify the action levels for the closure activities and the performance standards to be reached by the closure activities. The sampling section outlines the chronology, identifies the sample locations, and discusses how the samples were collected.

The closure activities section discusses the following topics: the closure activities for the structures, equipment, soil, and gravel scrubber; decontamination methods; materials made available for recycling or reuse; and waste management. The conclusion evaluates the results of the sampling and closure activities. The report determines that the areas addressed by the closure activities meet the performance standards and can be clean closed. 
WHC-SD-EN-EV-034, Rev. 1

This page intentionally left blank. 
WHC-SD-EN-EV-034, Rev. 1

\section{CONTENTS}

EXECUTIVE SUMMARY ................... i ii

GLOSSARY . . . . . . . . . . . . . . . . . . . . . . xi

1.0 INTRODUCTION . . . . . . . . . . . . . . . . . . . . 1

1.1 REGULATORY BACKGROUND ........................... 1

1.2 TREATMENT/STORAGE UNIT INFORMATION .............. 1 1.2.1 Treatment, Storage, and/or Disposal Unit Location . . . 2

1.2.2 Facility Description ............... 2

1.2.3 Operation as a Treatment, Storage, and/or

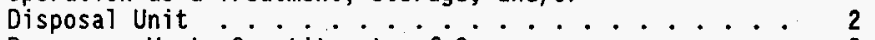

1.2.4 Dangerous Waste Constituents of Concerns:....... 2

1.2.5 Potentially Contaminated Media . . . . . . . . . 7

1.2.6 Radiological Contamination............ . 7

1.3 ClOSURE STRATEGY . . . . . . . . . . . . . . . . . 7

1.3.1 Strategy for Partial Clean Closure . . . . . . . 8

1.3.2 Subdivision of the 105-DR Large Sodium Fire Facility . . 8

2.0 ACTION LEVELS . . . . . . . . . . . . . . . . . . . . . 10

2.1 DEFINITION OF ACTION LEVELS FOR STRUCTURES

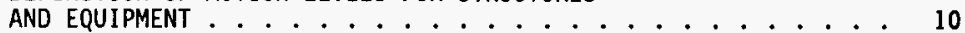

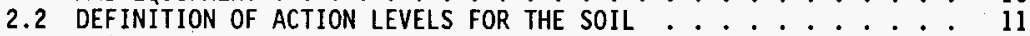

2.3 DEFINITION OF ACTION LEVELS FOR THE NEW SUBMERGED

GRAVEL SCRUBBER ..................... 11

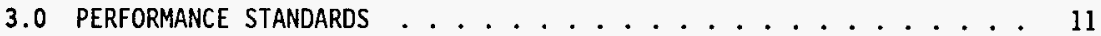

3.1 PRIMARY PERFORMANCE STANDARDS FOR STRUCTURES

AND EQUIPMENT . . . . . . . . . . . . . . . . . 12

3.2 PERFORMANCE STANDARDS FOR EQUIPMENT WITH LEAD/CARBONATE

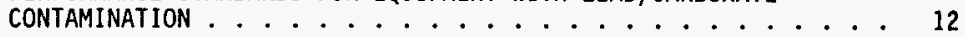

3.3 PERFORMANCE STANDARDS FOR THE GRAVEL SCRUBBER . . . . . . . . 12

3.4 PERFORMANCE STANDARDS FOR THE SOIL . . . . . . . . . . 12

4.0 SAMPLING . . . . . . . . . . . . . . . . . . . . 13

4.1 GENERAL SAMPLING INFORMATION ..................... 13

4.2 SAMPLING CHRONOLOGY .................... 13

4.3 AREA 7 SOIL SAMPLING ................... 13

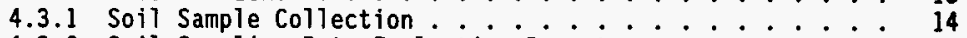

4.3.2 Soil Sampling Data Evaluation Report......... 14 


\section{CONTENTS (cont'd)}

4.4 AREA 3 GRAVEL SCRUBbER SAMPLING ................. 14

4.4.1 Gravel Scrubber Sample Collection ............ 14

4.4.2 Gravel Scrubber Sampling Deviation From Sampling Plan ................ 14

4.5 FIELD QUALITY ASSURANCE AND QUALITY CONTROL........... . 17

5.0 ClOSURE ACTIVITIES . . . . . . . . . . . . . . . . 17

5.1 CHRONOLOGY OF CLOSURE ACTIVITIES . . . . . . . . . . . 17

5.2 HANDLING OF DECONTAMINATION RESIDUES . . . . . . . . . . 17

5.3 CLOSURE ACTIVITIES FOR STRUCTURES AND EQUIPMENT . . . . . . . 18

5.3.1 Primary Decontamination Method ........... 18

5.3.2 Decontamination Method for Lead/Carbonate

Contamination .................. 18

5.4 CLOSURE ACTIVITIES FOR THE GRAVEL SCRUBBER . . . . . . . . 19

5.5 CLOSURE ACTIVITIES FOR THE SOIL . . . . . . . . . . . 19

5.6 DISCUSSION OF CLOSURE ACTIVITIES . . . . . . . . . . . 19

5.6.1 Overview of Closure Activities............ 19

5.6.2 Results of Visual Inspections ............. 20

5.6.3 Materials Made Available for Recycle or Reuses . . . . 21

5.6.4 Addressing Problems Found During Closure

Activities.................. 22

5.6.5 Waste Management ................. 22

5.6.6 Cracks in the Floors and Walls........... 23

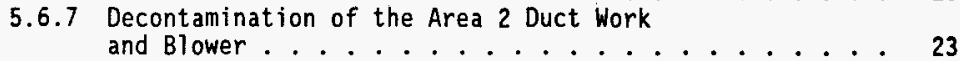

5.6.8 Radiological Aspects Related to the
Closure Activities..................... 24

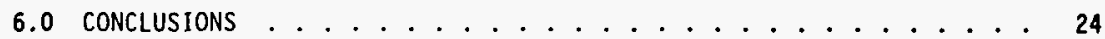

7.0 REFERENCES .......................... 25

7.1 DOCUMENTS . . . . . . . . . . . . . . . . . 25

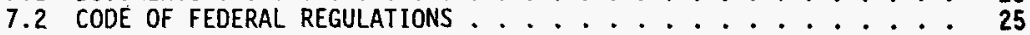

7.3 FEDERAL AND STATE ACTS . . . . . . . . . . . . 26

7.4 REVISED CODE OF WASHINGTON AND WASHINGTON

ADMINISTRATIVE CODE ................ 26 
WHC-SD-EN-EV-034, Rev. 1

CONTENTS (cont'd)

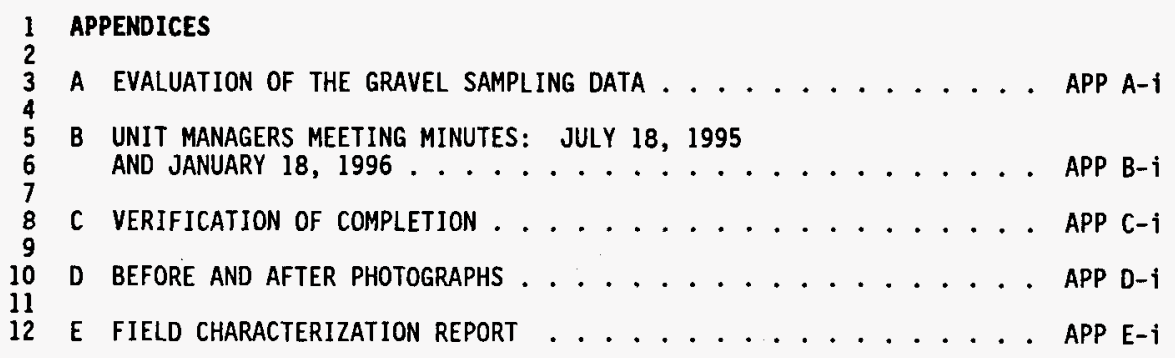


WHC-SD-EN-EV-034, Rev. I

FIGURES

1. The Hanford Site ................ . . 3

2. The 100-0 Area of the Hanford Site $\ldots \ldots \ldots$

3. A Schematic of the 105-DR Reactor Building Including the Large Sodium Fire Facility Prior to the Start of Closure Activities .................. 5

4. A Schematic of the Overall Large Sodium Fire Facility

10 Exhaust System as Used During Operations. . ......... 6

11 5. Sampling Locations at the 105-DR Large Sodium Fire Facility. . . . 15

12 6. Soil Random Sample Locations for Closure Area $7 \ldots \ldots$ 
WHC-SD-EN-EV-034, Rev. 1

4 CERCLA

5 CFR

6

7 DOE

8 DQO

9

10

11

12

13

17

LSFF

MTCA

psi

$Q A / Q C$

RCRA

TCLP

TSD

WAC

\section{GLOSSARY}

Comprehensive Environmental Response and Liability Act Code of Federal Regulations

U.S. Department of Energy

Data Quality Objective

Ecology Washington State Department of Ecology

EII Environmental Investigation Instruction

EPA U.S. Environmental Protection Agency

HEPA high-efficiency particulate air

IRIS Integrated Risk Information System

Large Sodium Fire Facility

Model Toxics Control Act

pounds per square inch

quality assurance/quality control

Tri-Party

Agreement

Resource Conservation and Recovery Act of 1976

Toxicity Characteristic Leaching Procedure

Hanford Federal Facility Agreement and Consent Order

treatment, storage, and/or disposal

Washington Administrative Code 
WHC-SD-EN-EV-034, Rev. 1

This page intentionally. left blank. 
WHC-SD-EN-EV-034, Rev. 1

\author{
105-DR LARGE SODIUM FIRE FACILITY \\ CLOSURE ACTIVITIES EVALUATION REPORT
}

\title{
1.0 INTRODUCTION
}

This report summarizes and evaluates the closure activities performed in support of partial closure of the 105-DR Large Sodium Fire Facility (LSFF). This evaluation will be used in assessing the condition of the 105-DR LSFF for the purpose of meeting the partial clean closure conditions described in the 105-DR Large Sodium Fire Facility Closure Plan (DOE-RL 1995). Based on the evaluation of the decontamination activities, sampling activities, and sample data, it is has been determined that the partial clean closure conditions for the 105-DR LSFF have been met.

\subsection{REGULATORY BACKGROUND}

The U.S. Environmental Protection Agency (EPA) and Washington State Department of Ecology (Ecology) jointly administer the Resource Conservation and Recovery Act of 1976 (RCRA) in the state of Washington. The EPA retains the oversight authority and delegates to Ecology the enforcement of a state program that is consistent with or more stringent than the corresponding Federal program. The implementing regulations are found in Title 40, code of Federal Regulations (CFR), Parts 260 to 270 and the Washington Administrative Code (WAC) 173-303, "Dangerous Waste Regulations." Ecology's authorization includes administering the closure of dangerous waste treatment, storage, and/or disposal (TSD) units.

The U.S. Department of Energy (DOE), the EPA, and Ecology have entered into an agreement called the Hanford Federal Facility Agreement and Consent order (Tri-Party Agreement) (Ecology et a1. 1996). This agreement affects environmental regulation of the Hanford Facility. One purpose of this agreement is to ensure that environmental impacts associated with past activities are investigated and appropriate response actions are taken, as necessary, to protect human health and the environment. The agreement seeks to promote this goal, in part, by identifying TSD units, identifying which units will undergo closure, and promoting compliance with relevant RCRA permitting requirements.

\subsection{TREATMENT/STORAGE UNIT INFORMATION}

The 105-DR LSFF is classified as a RCRA treatment unit. A fully detailed description of the unit and its history are included in the 105-DR Large Sodium fire Facility Closure Plan (DOE-RL 1995). 
WHC-SD-EN-EV-034, ReV. 1

\subsubsection{Treatment, Storage, and/or Disposal Unit Location}

The 105-DR LSFF is located in the southeast corner of the 100-D Area. The 105-DR LSFF is integral with the 105-DR Reactor. Schematics of the Hanford Site, the 100-D Area, and the 105-DR Reactor and the 105-DR LSFF prior to the start of the closure actitivities are shown in Figures 1, 2, and 3 , respectively.

\subsubsection{Facility Description}

The 105-DR LSFF primarily occupies the former supply fan room of the 105-DR Reactor Facility. The 105-DR LSFF a1so used parts of the 105-DR Reactor exhaust ducts and stack. A schematic of the 105-DR LSFF (including the 105-DR Reactor Building) is shown in Figure 3. A schematic of the 105-DR LSFF exhaust system prior to closure is shown in figure 4.

The 105-DR Reactor Facility was designed and built in the 1950's and ceased operation in 1964. The 105-DR Reactor Building is a non-airtight industrial structure built of reinforced concrete in the lower portions and concrete block in the upper portions. The roof is constructed of reinforced concrete or precast concrete roof tile, depending on the specific roof area. Installation of the 105-DR LSFF into the 105-DR Reactor Building was completed in 1972. A new submerged gravel scrubber, blower, and duct work connecting the new submerged gravel scrubber to the 105-DR Reactor exhaust system was installed in 1982 (Figures 3 and 4).

\subsubsection{Operation as a Treatment, Storage, and/or Disposal Unit}

The 105-DR LSFF was established to provide a means of investigating fire and safety aspects associated with sodium or other metal alkali fires in the liquid metal fast breeder reactor facilities. The 105-DR LSFF initially was used only for engineering-scale alkali metal reaction studies. Additionally, the Fusion Safety Support Studies program sponsored intermediate-size safety reaction tests in the 105-DR LSFF with lithium and lithium lead compounds.

The facility also has been used to store and treat alkali metal waste, specifically, metallic sodium and lithium waste with the characteristic of reactivity, and is assigned the dangerous waste number 0003 . Therma? treatment (burning) was used as the treatment method for addressing the characteristic of reactivity.

\subsubsection{Dangerous Waste Constituents of Concerns}

The dangerous waste treated and stored at the 105-DR LSFF was metallic sodium and metallic lithium. Both of these are reactive metals that spontaneously react with the moisture in the air to produce sodium bicarbonate and lithium carbonate. Also, the combustion of metallic sodium and metallic lithium produce these same carbonates. Because of the their reactivity, no metallic sodium or metallic lithium will be found at the 105-DR LSFF. Sodium bicarbonate and lithium carbonate are considered to be the waste residue from 
WHC-SD-EN-EV-034, Rev. I

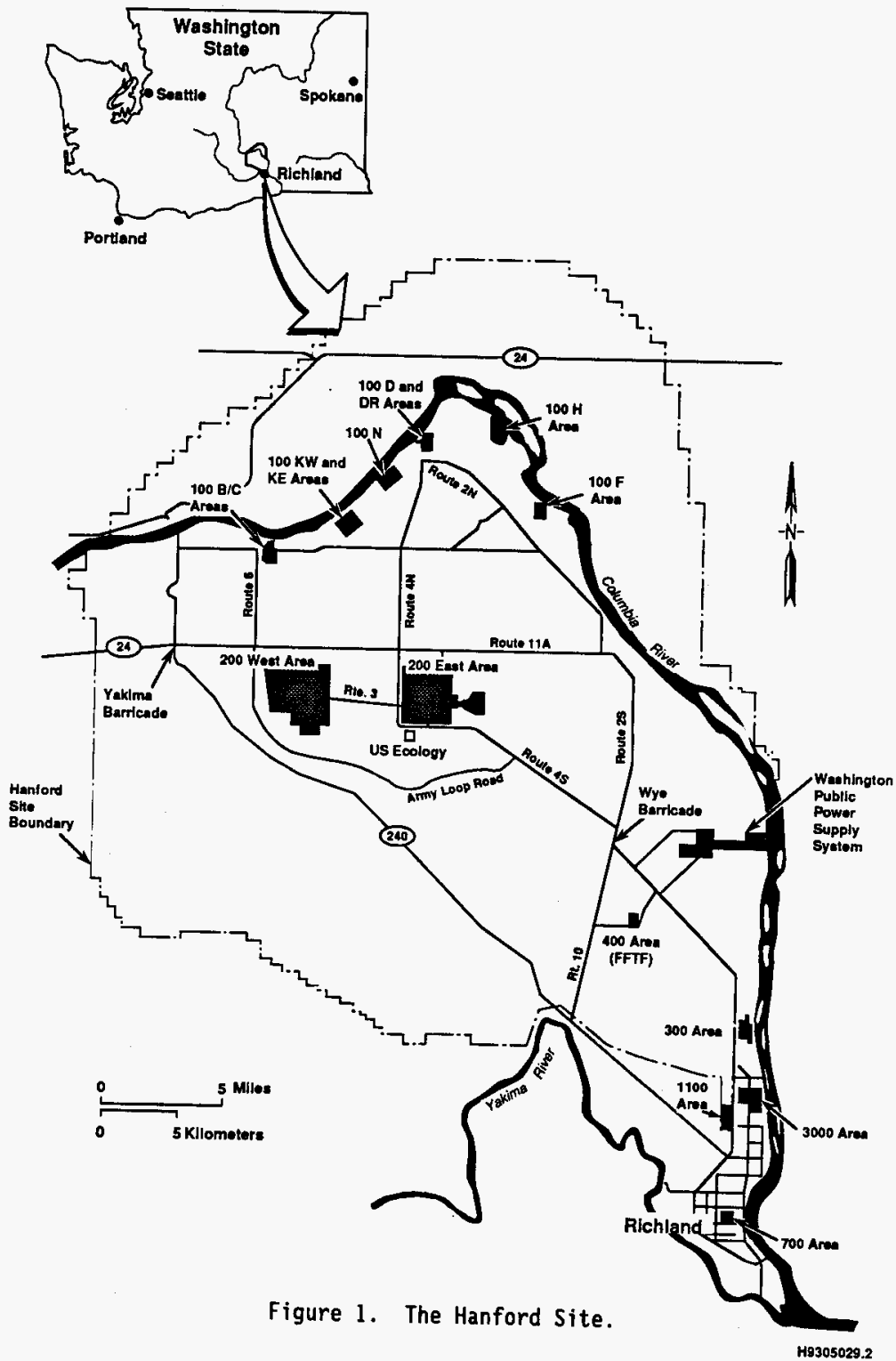


WHC-SD-EN-EV-034, Rev. 1

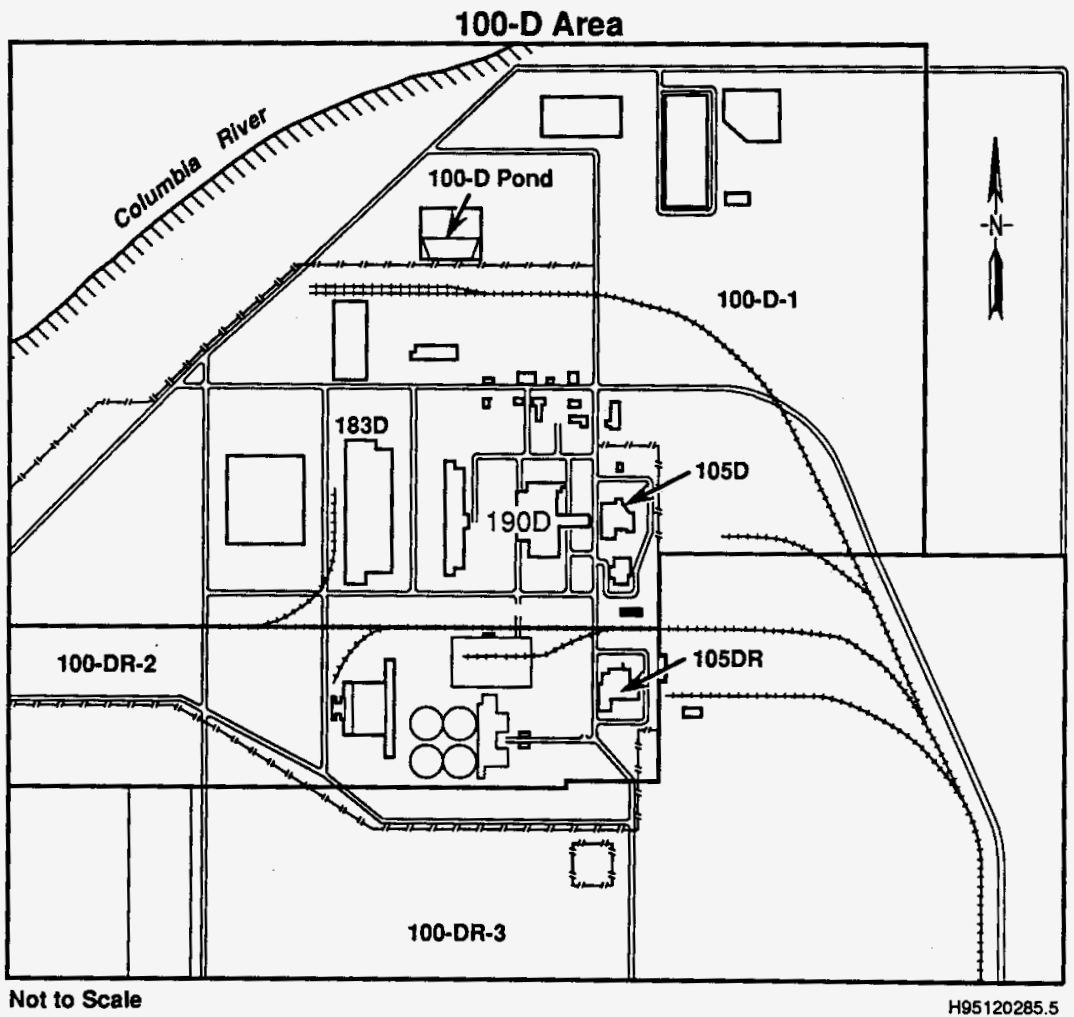

Figure 2. The 100-D Area of the Hanford Site. 


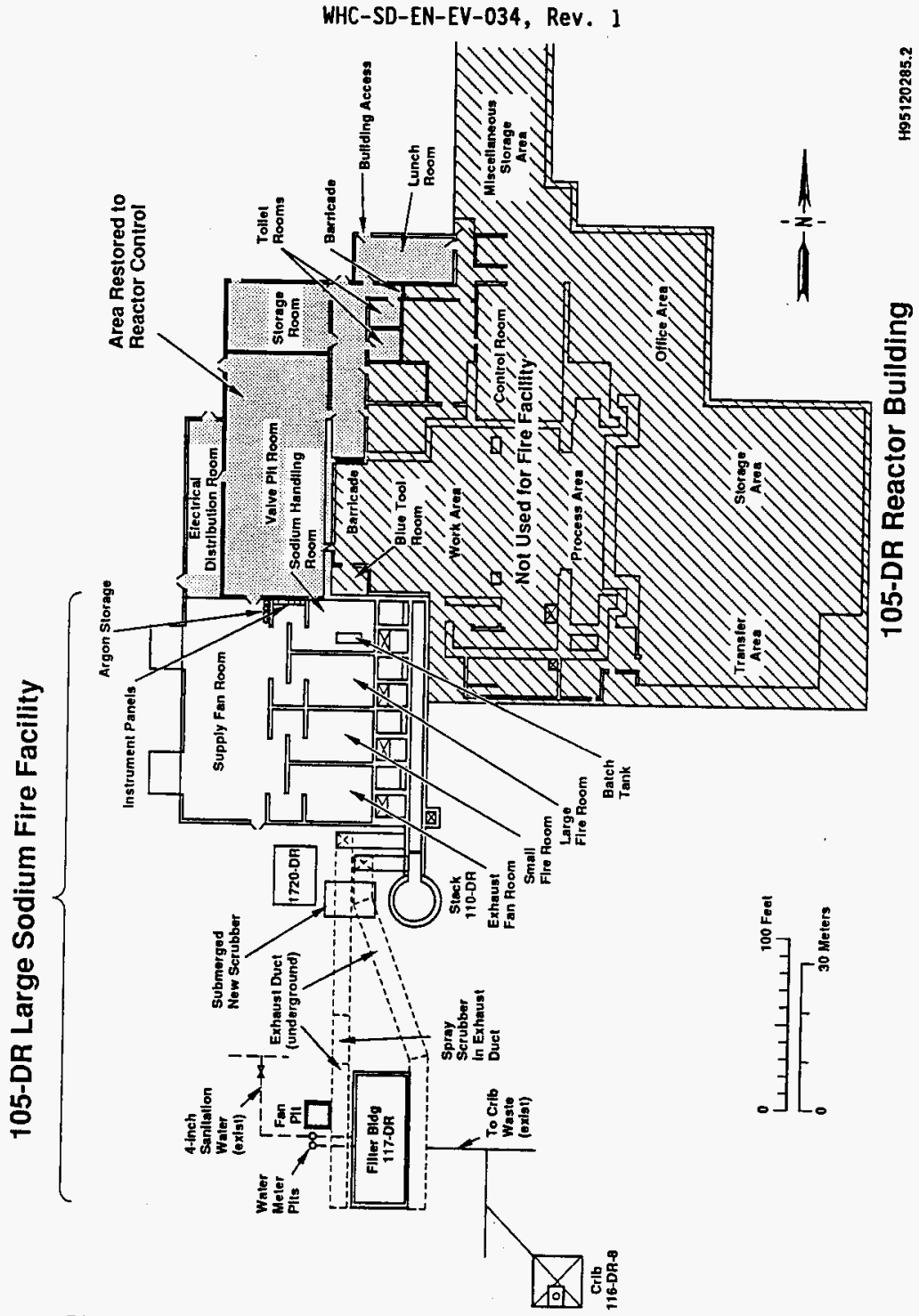

Figure 3. A Schematic of the 105-DR Reactor Building Including the Large Sodium Fire Facility Prior to the Start of Closure Activities. 


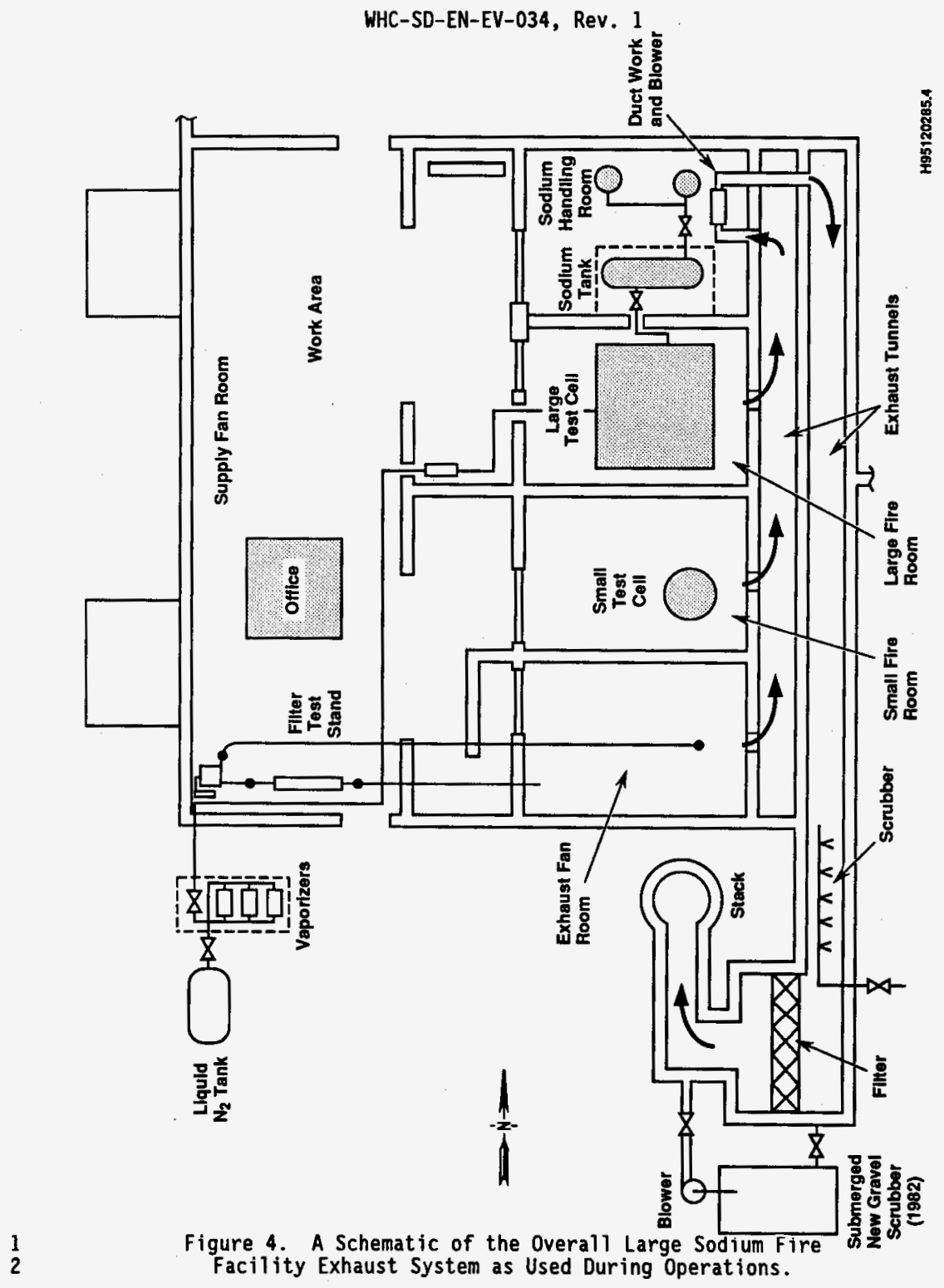


1 the operation of the 105-DR LSFF. Therefore, sodium bicarbonate and lithium carbonate are considered to be the constituents of concern.

Note that sodium bicarbonate and lithium carbonate are not hazardous wastes regulated by RCRA. The are regulated as dangerous wastes under WAC 173-303.

A lithium-lead alloy is known to have been burned at the 105-DR LSFF. Lead is regulated by both RCRA and WAC 173-303 and also is subject to the Land Disposal Restrictions in 40 CFR 268. The burning of the lead-lithium alloy may have occurred in one of two pressure vessels: the Small Test Cell in the Smal1 Fire Room or in an instrumented pressure vesse1 from the Large Fire Room's Large Test Cell. Because of the burning of the alloy, there is a potential for lead contamination in the Small Test Cell and in the instrumented pressure vesse1. Therefore, lead is an additional constituent of concern for the Small Test Cell and the instrumented pressure vessel.

\subsubsection{Potentially Contaminated Media}

Potentially contaminated media at the 105-DR LSFF included the concrete building structure and the equipment used to contain the sodium and lithium fires, and the exhaust system. The exhaust system consisted of steel piping, steel ducting, and concrete ducts. Specific structures associated with the exhaust system include the 110-DR Stack, the 117-DR Filter Building, the 116-DR-8 Crib, and the new submerged gravel scrubber. Areas of potential soil contamination included the area immediately south of the reactor building out to about the south end of the 117-DR Filter Building (see figures 3 and 4 ).

\subsubsection{Radiological Contamination}

No radiologically contaminated material was burned during the operation of the 105-DR LSFF. However, parts of the 105-DR Reactor exhaust system are either known or suspected to be radiologically contaminated from operation of the 105-DR Reactor. The areas that are known or suspected to be radiologically contaminated are: the concrete duct work from the 105-DR Building to the 117-DR Filer Building, the 117-DR Filter Building, the concrete duct work from the Filter Building to and including the 110-DR Stack, and the 116-DR-8 Crib (see Figures 3 and 4 ).

\subsection{CLOSURE STRATEGY}

The closure strategy for the 105-DR LSFF is to divide the closure into two parts as follows:

1. Partial clean closure of the 105-DR LSFF under WAC 173-303-610(b) as specified in the 105-DR Large Sodium Fire Facility Closure Plan (DOE-RL 1995). Partial clean closure addresses those areas of the 105-DR LSFF that are not radiologically contaminated. 
WHC-SD-EN-EV-034, Rev. 1

2. Final closure of the radiologically contaminated portion of the 105-DR LSFF as part of the decontamination and decommissioning of the 105-DR Reactor. Overall remediation of the 105-DR Reactor will occur under the Comprehensive Environmental Response and Liability Act of 1980 (CERCLA) remedial action process. The WAC 173-303 closure requirements will be integrated into the CERCLA remedial action process.

This report only addresses the partial clean closure of the 105-DR LSFF. The scope and timetabie for the final closure are beyond the scope of this report.

\subsubsection{Strategy for Partial Clean Closure}

The strategy for partial clean closure is specified in Chapters 6 and 7 of the 105-DR Large Sodium Fire Facility Closure Plan (DOE-RL 1995). The strategy for partial clean closure is summarized as follows:

1. Decontaminate or remove the structures and equipment as specified in the closure plan.

2. Dispose of decontamination residues and contaminated equipment in accordance with applicable regulations as determined by sampling.

3. Sample soil to determine if sodium and lithium are below dangerous waste levels.

4. Evaluate the soil data for quality assurance/quality control (QA/QC) reliability and significant contamination levels in comparison with the soil action levels.

5. Conduct additional decontamination of the 105-DR LSFF, as required.

6. Certify that closure activities were completed in accordance with the approved closure plan.

\subsubsection{Subdivision of the 105-DR Large Sodium fire Facility}

The 105-DR LSFF has been subdivided into seven distinct areas. The following is a description of each area prior to the start of closure activities. Areas 1,3 , and 7 have been addressed by these closure activities. The blower and duct work that is part of Area 2 has also been addressed by these closure activities.

1.3.2.1 Area 1. Area 1 consists of the Exhaust Fan Room, the Large Fire Room, the Small Fire Room, the Sodium Handling Room, and an office/work area.

The Exhaust Fan Room contained several burn pans, a ceiling mounted hoist, and various utility fixtures. The sodium and lithium burns occurred in open, large, shallow steel pans. Before the start of the closure activities, the sump in the Exhaust Fan Room contained about 4 liters (1 gallon) of crusty powder and reaction by-products from past burns. 0ld burn pans stored in this 
1 room still contained residues. There also was a carbonate coating on the 2 walls, light fixtures, and other equipment.

The Small Fire Room contained the Small Test Cell. There also was a duct work running from the Small Test Cell to the reactor exhaust tunnel. The Smal1 Test Cell was a cylindrical, steel pressure vessel used for various burn tests. In addition to sodium and lithium metal, lithium-lead compounds may have been burned in this test cell. Before the start of the closure activities, the Small Test Cell had a thin coating of carbonate on the internal surfaces.

The Large Fire Room contained the Large Test Cell. The Large Test Cell was a large, square steel chamber. Associated with this test cell was a sma11, instrumented pressure vessel. This instrumented pressure vessel was a 1.8-meter (6-foot) tall, cylindrical steel pressure vessel. In addition to sodium and 1ithium metal, 1ithium-lead compounds may have been burned in the instrumented pressure vesse1. There was duct work running from the Large Test Cell into the reactor exhaust tunnel. Before the start of closure activities, there was carbonate on the internal surfaces of this cell as well as on the top.

The Sodium Handling Room contained an insulated stainless steel sodium storage tank. The Area 2 duct work and blower that connects the upper and lower exhaust tunnels was physically located in this room. Before the start of closure activities, the sodium storage tank was empty and there was carbonate coating the interior surfaces of the ducts.

The office/work area of the Fan Supply Room is considered to be clean. However, this area contained the Filter Test Stand and the associated piping between the test stand, the Large Test Cell, and the Exhaust Fan Room. This equipment was expected to be contaminated with carbonates.

Area 1 was fully addressed by these closure activities.

1.3.2.2 Area 2. Area 2 consisted of the upper and lower exhaust tunnel, the biower and associated duct work that moved 105-DR LSFF exhaust from the lower to the upper tunnel, and the exterior underground tunnel to the 117-DR Filter Building (south of the 105-DR LSFF). These tunnels had low but measurable radioactivity when sampled in 1987. The tunnels were not addressed by these closure activities. Closure of the tunnels will be deferred until remediation of the 105-DR Reactor.

The blower and associated duct work were included as part of the closure activities. They were located in the Sodium Handling Room (Figure 4) within the boundaries of Closure Area 1. Including the blower and associated duct work in the closure activities allowed the tunnel to be isolated and removed carbonate contaminated equipment from within the physical boundaries of Closure Area 1.

\subsubsection{Area 3. Area 3 consisted of the new submerged (1982) grave1} scrubber, blower, ducts, scrubber housing, and the gravel. Operation of the new submerged gravel scrubber, blower, and ducts occurred 16 years after the 105-DR Reactor ceased operations; consequently, no radioactivity is expected. This area was addressed by these closure activities. 
1.3.2.4 Area 4. Area 4 consists of the 117-DR Filter Building and the downstream tunnel to the reactor stack. The original high-efficiency particulate air (HEPA) filters from the 105-DR Reactor reportedly were replaced for the operation of the LSFF. This area is considered to be radiologically contaminated. Closure will be deferred until remediation of the 105-DR Reactor.

1.3.2.5 Area 5. Area 5 consists of the reactor exhaust stack. This area is considered to be radiologically contaminated. Closure will be deferred until remediation of the 105-DR Reactor.

1.3.2.6 Area 6. Area 6 consists of the 116-DR-8 Crib. The 116-DR-8 Crib originally was used from 1960 to 1964 to percolate low-level radioactive waste drainage from the 117-DR Building seal pits. When used for the 105-DR LSFF, the 116-DR-8 Crib received only water from the gravel scrubbers. The 105-DR Large Sodium Fire Facility Closure Plan (DOE-RL 1995) has reported that the water sent to the 116-DR-8 Crib was not corrosive (i.e., the pH level of the water was less than 12.5).

The 116-DR-8 Crib is radiologically contaminated. The 116-DR-8 Crib also is part of the 100-HR-3 Ground Water Operable Unit and the 100-DR-2 Operable Unit (Ecology et al. 1996). Closure will be deferred until remediation of these operable units.

1.3.2.7 Area 7. Area 7 consists of the soil area to the north and west of the 117-DR Filter Building. The burn pans used in the alkali metal fires were sometimes stored in this area. This area will be addressed by these closure activities.

In summary, the closure will be 1 imited to Area 1, Area 3, and Area 7 . Also addressed is the Area 2 blower and duct work that is physically located in Area 1.

\subsection{ACTION LEVELS}

Action levels are concentrations of the constituents of concern that prompt an action, such as removal/disposal, treatment, or further evaluation. The action levels for these closure activities were based on the requirements of the 105-DR Large Sodium Fire Facility Closure Plan (DOE-RL 1995) and the Data Quality objective (DQO) meetings held with Ecology during the first half of 1995 .

\subsection{DEFINITION OF ACTION LEVELS FOR STRUCTURES AND EQUIPMENT}

The initial action level for the structures and equipment was the visible presence of carbonates. If carbonates were visible, then the structure or equipment either was decontaminated or dismantled for disposal. 


\subsection{DEFINITION OF ACTION LEVELS FOR THE SOIL}

The initial action levels for the soil were the greater of two levels for sodium and lithium: Sitewide Soil Background values defined in Hanford Site Background: Part 1, Soil Background for Nonradioactive Analytes (DOE-RL 1994) or Model Toxics Control Act (MTCA) cleanup values defined in the Model Toxics Control Act Cleanup Regulations (WAC 173-340). If concentrations of the constituents of concern in the soil exceeded initial action levels, then the requirements of WAC $173-340-610$ would be invoked to assess the action levels.

\subsection{DEFINITION OF ACTION LEVELS FOR THE NEW SUBMERGED GRAVEL SCRUBBER}

The duct work, blowers, and housing of the new submerged gravel scrubber are considered to be equipment. Therefore, they used the structures and equipment action level (Section 2.1).

The gravel in the new submerged gravel scrubber used action levels based on the Toxicity Characteristic Leaching Procedure (TCLP) metals analysis (Test Methods for the Evaluation of Solid Waste: Physical/Chemical Methods [EPA 1986]) and on corrosivity. The concern of the TCLP metals analysis was to determine if the gravel contains sufficient metals to designate as a dangerous waste.

The corrosivity initial action level for the gravel was a pH less than or equal to 2 and equal to or greater than 12.5 . A pH between 2 and 12.5 was nondangerous.

The TCLP metal initial action level for the gravel was the greater of the Sitewide Soil Background values or MTCA cleanup values. The Sitewide Soil Background concentrations are defined in Hanford Site Background: Part 1, Soil Background for Nonradioactive Analytes (DOE-RL 1994). The MTCA cieanup values are defined in the Model Toxics Control Act Cleanup Regulations (WAC 173-340).

If concentrations of the constituents of concern in the gravel had exceeded the initial action levels, then the gravel would have been considered to be a dangerous waste and disposed according to the requirements of WAC 173-303.

\subsection{PERFORMANCE STANDARDS}

The specific performance standards to be used for the closure of the 105-DR LSFF were defined by the requirements of the 105-DR Large Sodium Fire Facility Closure Plan (DOE-RL 1995), the 105-DR Large Sodium Fire Facility Decontamination, Sampling, and Analysis Plan (WHC 1995), and the DQO meetings held with Ecology during the first half of 1995 . 
WHC-SD-EN-EV-034, Rev. 1

\subsection{PRIMARY PERFORMANCE STANDARDS FOR STRUCTURES AND EQUIPMENT}

The performance standard for the structures and equipment with only carbonate contamination was a visually clean surface with no carbonate present.

\subsection{PERFORMANCE STANDARDS FOR EQUIPMENT WITH LEAD/CARBONATE CONTAMINATION}

The performance standard for equipment with suspected lead and carbonate contamination was the "clean debris surface" specified in 40 CFR 268. A clean debris surface is defined in 40 CFR 268.45, Table 1 as:

"'Clean debris surface' means the surface, when viewed without magnification, shall be free of all visible contaminated soil and hazardous waste except that residual staining from soil and waste consisting of light shadows, slight streaks, or minor discolorations, and soil and waste in cracks, crevices, and pits, may be present provided that such staining and waste and soil in cracks, crevices, and pits sha1l be limited to no more than 5 percent of each square inch of surface area."

\subsection{PERFORMANCE STANDARDS FOR THE GRAVEL SCRUBBER}

The equipment portion of the gravel scrubber used the performance standard defined in Section 3.1. The performance standard for the gravel from the gravel scrubber was designation or nondesignation as dangerous waste. The criteria for designation is discussed in Section 1.4.3. If designated as dangerous waste, the gravel would have been managed as a dangerous waste per the requirements of WAC 173-303. If it did not designate as dangerous waste, the gravel would have been disposed of as a nonregulated solid waste or reused/recycled.

\subsection{PERFORMANCE STANDARDS FOR THE SOIL}

The performance standard for the soil was concentrations of sodium and lithium concentrations that are higher than one of two levels: Sitewide Soil Background values or MTCA cleanup values. The Sitewide Soil Background concentrations are defined in Hanford Site Background: Part 1, Soil Background for Nonradioactive Analytes (DOE-RL 1994). The MTCA cleanup values are defined in the Model Toxics Control Act Cleanup Regulations (WAC 173-340). Note that the performance standard was the same as the action levels defined in Section 2.2 . 
WHC-SD-EN-EV-034, Rev. 1

\subsection{SAMPLING}

Sample collection occurred at the 105-DR LSFF during July 1995. The soil samples from Area 7 were collected on July 18, 1995. The samples from the new submerged gravel scrubber (Area 3) were collected on July 20, 1995. Sampling was conducted in accordance with the 105-DR Large Sodium Fire Facility Decontamination, Sampling, and Analysis Plan (WHC 1995), except as noted. This plan is the implementing document for the Chapter 6 and Chapter 7 requirements of the 105-DR Large Sodium Fire Facility Closure Plan (DOE-RL 1995).

\subsection{GENERAL SAMPLING INFORMATION}

The sample locations at the 105-DR LSFF were finalized during informal DQO meetings held between Ecology and DOE during the first half of 1995 . The sampling locations are documented in the 105-DR Large Sodium fire Facility Decontamination, Sampling, and Analysis Plan (WHC 1995).

A11 sampling equipment used at the 105-DR LSFF were decontaminated in the $1706 \mathrm{KE}$ Laboratory in accordance with Environmental Investigation Instruction (EII) 5.5, "1706 KE Laboratory Cleaning of RCRA/CERCLA Sampling Equipment" (Environmental Investigations and Site Characterization Manual [WHC 1988]). All sampling equipment (shovel, spoons, bowls, grain sampler) were made from stainless steel.

\subsection{SAMPLING CHRONOLOGY}

The following lists the chronology of critical events associated with the sampling at the 105-DR Large Sodium Fire Facility:

- May 25, 1995 Ecology approves use of the draft decontamination, sampling, and analysis plan

- Jun 5, 1995 105-DR Large Sodium Fire Facility Decontamination, Sampling, and Analysis Plan (WHC 1995) issued

- Jul 18, 1995 Area 7 Soil sampling started and completed

- Jul 20, 1995 Area 3 Scrubber gravel sampling started and completed.

\subsection{AREA 7 SOIL SAMPLING}

The Area 7 soil samples were fully evaluated in the 105-DR Large Sodium Fire Facility Soil Sampling Data Evaluation Report (WHC 1996). The results of this report will be summarized. 
There are a total of 5 soil sample locations in Area 7: 2 random and 3 authoritative. Figure 5 shows the general locations of the soll samples. The specific locations of the Area 7 random samples are shown on Figure 6 . A total of 6 soil samples were collected: 2 random soil samples, 1 random duplicate soil sample, and 3 authoritative soil samples.

\subsubsection{Soll Sample Collection}

At each location, the top 150 millimeters (6 inches) of soil was removed with a clean shovel. The sample was then mixed in a clean bowl and placed into vendor-certified clean bottles using clean spoons.

\subsubsection{Soil Sampling Data Evaluation Report Errata}

There are two known typographical errors in the 105-DR Large Sodium Fire Facility Soil Sampling Data Evaluation Report (WHC 1996). Both are located on page F3, Figure 3. The first is "Authoritative Sample 3 (BOG984)" should read "Authoritative Sample 3 (BOG982)." The second is "Authoritative Sample 2 (BOG985)". should read "Authoritative Sample 2 (BOG984)."

\subsection{AREA 3 GRAVEL SCRUBBER SAMPLING}

The Area 3 gravel scrubber samples were evaluated fully in Appendix A. The results of this appendix will be summarized. There are a total of 2 gravel scrubber sample locations. These locations are shown in Figure 5.

\subsubsection{Gravel Scrubber Sample Collection}

Two entry holes were cut into the south side of the gravel scrubber with an acetylene torch. One entry hole was orientated toward the west side of the scrubber with the other being oriented toward the east side. The torch also was used to cut holes in the screen covering the gravel. A grain sampler was inserted into the gravel bed as far as possible. The gravel sample was composited in a clean bowl and placed into vender certified clean bottles using clean spoons.

\subsubsection{Gravel Scrubber Sampling Deviation From Sampling Plan}

There was one deviation from the approved 105-DR Large Sodium Fire Facility Decontamination, Sampling, and Analysis Plan (WHC 1995). Section 4.0 of the 105-DR Large Sodium Fire Facility Decontamination, Sampling, and Analysis Plan (WHC 1995) states that "These samples will be obtained as the gravel is removed from the scrubber." The need to designate the gravel prior 
WHC-SD-EN-EV-034, Rev. 1
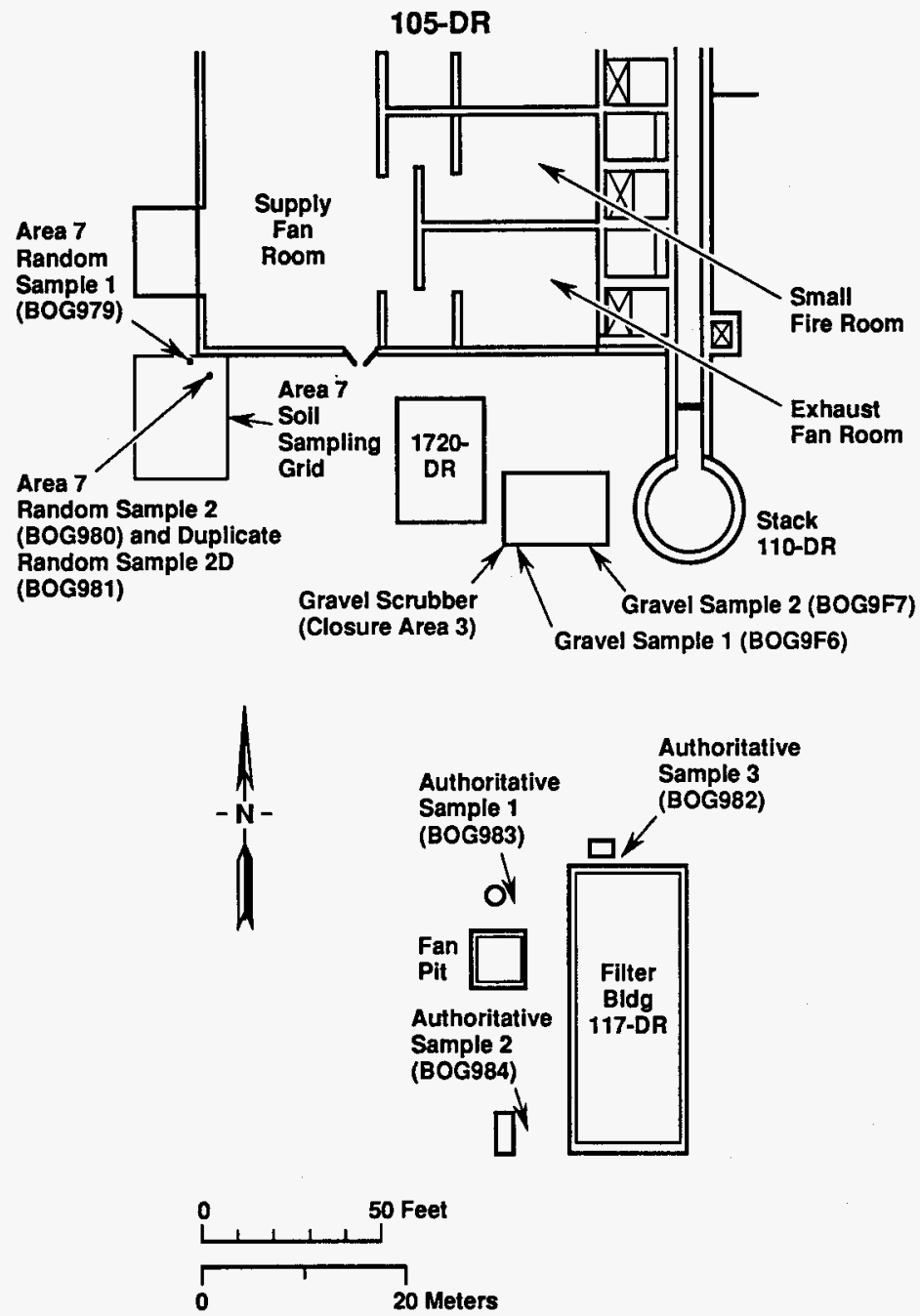

H9508018.1

Figure 5. Sampling Locations at the 105-DR Large Sodium Fire Facility. 


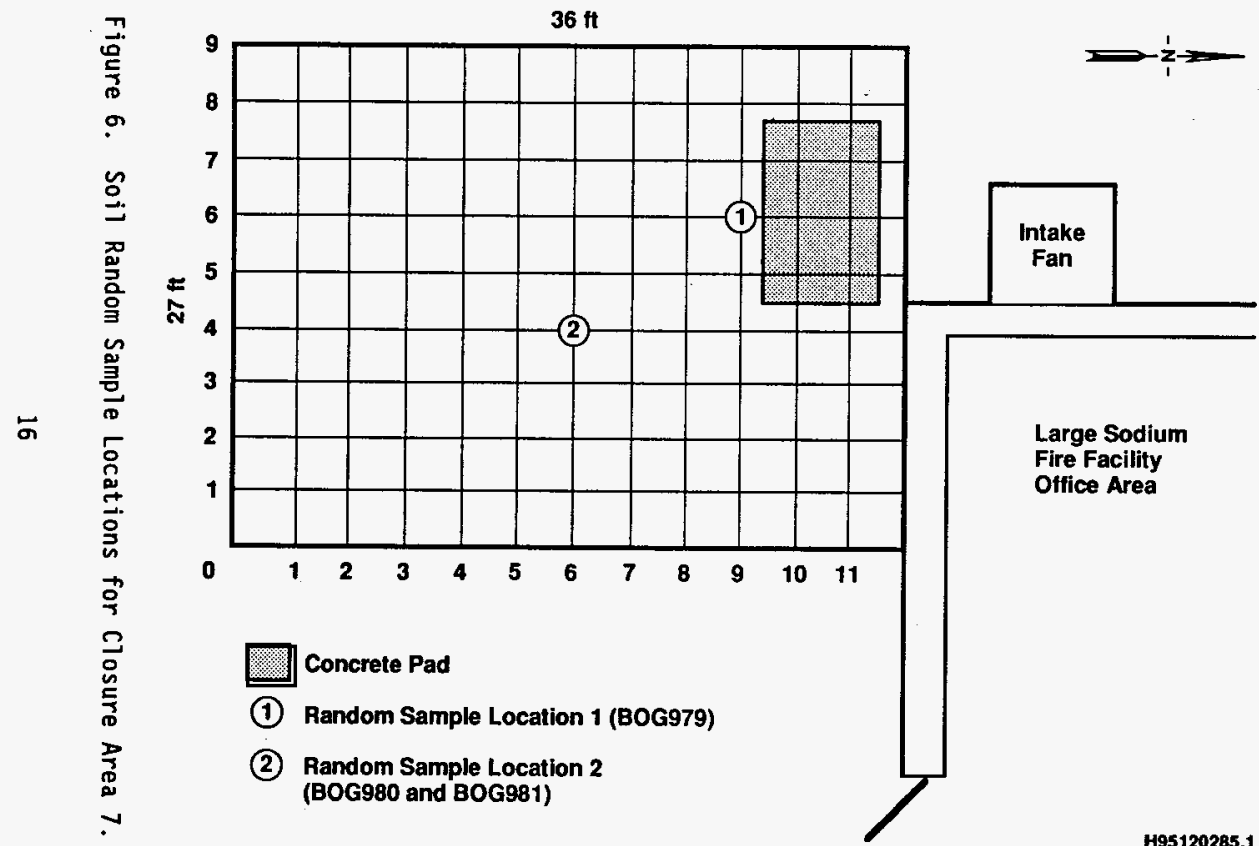


44

to removal prevented the samples from being taken during removal. During the July 18,1995 , meeting with Ecology, the following deviation was agreed on:

1. Sample the gravel in place

2. Analyze the gravel sample

3. Evaluate the results

4. Dispose of the gravel appropriately.

The gravel sample to support closure was collected on July 20, 1995. Removal started on March 4, 1996, and was completed by March 13, 1996. This deviation did not have any adverse affects on the results of either the sampling or the closure activities. A copy of the July 18, 1995, meeting minutes are presented in Appendix B.

\subsection{FIELD QUALITY ASSURANCE AND QUALITY CONTROL}

Per the 105-DR Large Sodium Fire Facility Decontamination, Sampling, and Analysis Plan (WHC 1995), field and trip blanks were not used because no volatile organic samples were collected. Equipment blanks were not required because field decontamination of sampling equipment was not used.

\subsection{CLOSURE ACTIVITIES}

The closure activities followed the requirements of the 105-DR Large Sodium Fire Facility Closure Plan (DOE-RL 1995). Several aspects of the closure activities from Chapters 6 and 7 of the closure plan are identified in greater detail in 105-DR Large Sodium Fire Facility Decontamination, Sampling, and Analysis Plan (WHC 1995). This document was reviewed and approved by Ecology prior to the start of the closure activities.

\subsection{CHRONOLOGY OF CLOSURE ACTIVITIES}

The closure activities started in July 1995 with the sampling of the soil and the gravel scrubber. The other activities that occurred from July 1995 to the end of September 1995 were equipment procurement and setup.

Decontamination efforts started in ernest during October 1995 with the start of the new fiscal year. The closure activities were completed in March 1996.

\subsection{HANDLING OF DECONTAMINATION RESIDUES}

To ensure proper handling of decontamination residues, a less-than-90-day storage area and satellite accumulation areas were established in the 105-DR LSFF. The decontamination residues and any other wastes (e.g., light ballasts) were handled according to the requirements of WAC 173-303. 
WHC-SD-EN-EV-034, Rev. 1

\subsection{CLOSURE ACTIVITIES FOR STRUCTURES AND EQUIPMENT}

For the structures and equipment, the action level was the visible presence of carbonate (Section 2.1). When visible carbonates were present, the structure and equipment were decontaminated to the appropriate performance standard. The decontamination method and performance standard was dependant on the suspected presence of lead. A more rigid decontamination method and performance standard was used for the two pieces of equipment that were suspected to have lead contamination. Additional detail on the decontamination of the structures and equipment is given in Section 5.6.

\subsubsection{Primary Decontamination Method for Structures and Equipment}

The primary decontamination method for structures and equipment began by removing any bulk carbonate using physical methods (e.g., scrapping). A mild nonhazardous acetic acid solution was used to remove any remaining carbonate. The mild nonhazardous acetic acid solution consisted of 1 percent acetic acid and 99 percent water.

If the building structure was being decontaminated, then it was subjected to a pressure wash using the mild acetic acid solution. As needed, limited areas of the building structure were decontaminated using hand methods (e.g., scrub brushes and the mild acetic acid solution).

The main method of decontamination for the equipment was by hand using scrub brushes in the mild acetic acid solution. This method was used on the equipment from Area 1 and Area 3. Equipment being decontaminated also may have required the use of the pressure wash.

The performance standard for structures and equipment with only carbonate contamination is discussed in Section 3.1 .

\subsubsection{Decontamination Method for Lead/Carbonate Contamination}

The Small Test Vessel and the instrumented pressure vessel from the Large Test Cell may have had lead contamination. Lead requires a more stringent treatment technology than the carbonate. To address the lead contamination while avoiding costly sampling, it was decided to use the "Debris Rule" treatment technologies listed in 40 CFR 268. The 105-DR Large Sodium Fire Facility Decontamination, Sampling, and Analysis Plan (WHC 1995), identified that wet sandblasting would be used for the carbonate/lead decontamination.

Because of concerns related to minimizing waste handling when using the garnet wet sandblasting, a high pressure $(40,000$ pounds per square inch [psi]) water blasting was used for the decontamination. Both technologies are on the Debris Rule (40 CFR 268) list of approved treatment technologies, are equivalent for the intended use, and have the same performance standard (Section 3.2). Ecology was informed of the change prior to the start of the decontamination. The change and Ecology's consent was documented in the Unit Manager's Meeting Minutes dated January 18, 1996 (Appendix B). 
WHC-SD-EN-EV-034, ReV. 1

The performance standard for structures and equipment with only carbonate and lead contamination is discussed in Section 3.2 .

\subsection{CLOSURE ACTIVITIES FOR THE GRAVEL SCRUBBER}

During closure activities, the gravel scrubber (Area 3) was subdivided into two parts. The first part was the equipment: the ducts, the blower, and the scrubber housing. The second part was the gravel inside the scrubber housing. The ducts, blower, and housing were treated as equipment and handled according to the general closure activities outlined in Section 5.3.1. Additional detail on the decontamination and dismantling of the gravel scrubber is given in Section 5.6.

There was one deviation from the 105-DR Large Sodium Fire Facility Decontamination, Sampling, and Analysis Plan (WHC 1995). This deviation is associated with sampling the gravel and is discussed in Section 4.4.2. This deviation did not have any adverse affects on the results of either the sampling or the closure activities.

Evaluation of the gravel sampling (Appendix A) determined that the gravel performance standards (Section 3.3) were met. Therefore, the gravel did not require disposal as a dangerous waste and was available for reuse.

\subsection{CLOSURE ACTIVITIES FOR THE SOIL}

Evaluation of the soil sampling (105-DR Large Sodium Fire Facility Soil Sampling Data Evaluation Report [WHC 1996]) determined that the soil performance standards (Section 3.4) were met. Therefore, the soil was clean and did not contain any contamination. No closure activities were needed for the soil.

\subsection{DISCUSSION OF CLOSURE ACTIVITIES}

Closure activities started on October 3, 1995, and were completed on March 15, 1996.

\subsubsection{Overview of Closure Activities}

As decontamination of each part of the 105-DR LSFF proceeded, 100se equipment was gathered and moved as necessary to alleviate any safety (e.g., tripping) hazards. Then, any other safety concerns (e.g., isolation of electrical systems) were addressed.

Equipment was then disassembled as required and decontaminated. Decontamination continued until the equipment met the performance standard requirements of Section 3.1 . Solid carbonate was collected into satellite drums, then a water and mild acid solution was used to decontaminate the equipment to a visually clean surface. The liquid waste was collected in 


$$
\text { WHC-SD-EN-EV-034, Rev. } 1
$$

1 drums. Then, the clean equipment was stockpiled for either recycle

2 (e.g., scrap metal) or reuse (various types of equipment).

3

4

The interiors of the Small Test Cell and the instrumented pressure vessel from the Large Test Cell were decontaminated to remove lead and carbonate contamination using a high pressure (40,000 psi) water blast. After decontamination, the interiors of both pieces of equipment met the performance standard requirements of Section 3.2. Verification of the decontamination is included in Appendix C.

As part of the closure, all penetrations from the Exhaust Fan Room, Small Fire Room, Large Fire Room, and Sodium Handling Room into the reactor exhaust tunnels system were sealed. This isolated Closure Area 1 from any carbonate or radiological cross-contamination from Closure Area 2.

The Exhaust Fan Room, Small Fire Room, Large Fire Room, and Sodium Handling Room also were washed down using the pressure washing equipment and the water and mild acid solution. This removed any carbonate remaining on the walls. The spraying was conducted using the minimum amount of liquid possible. The waste liquid was collected and drummed during the spraying operations to prevent a buildup of liquid. Several complete washing evolutions per room were required to remove the carbonate and to obtain a visually clean surface that met the performance requirements of Section 3.1 .

Also decontaminated at this time were the burn pans and other equipment that had been stored outside in Area 7 . The filter test stand and its associated duct work were disassembled and decontaminated. Minor decontamination and major dismantling work was required for the control room outside the Small Fire Room; the temperature, instrumentation, and gas flow control equipment outside the Large Fire Room; and the Sodium Handling Room.

The duct work to and from the gravel scrubber and the associated blower were dismantled and decontaminated. This equipment was very clean and required only a minimum of decontamination. The penetrations into the reactor exhaust system were then sealed. This will prevent any carbonate or radiological contamination from spreading out of Closure Area 2 and Closure Area 4.

The gravel from the new submerged gravel scrubber initially was placed into drums and handled as a potentially dangerous waste. Once the internal waste designation process confirmed that the gravel did not designate as dangerous waste under WAC 173-303, it was made available for reuse.

\subsubsection{Results of Visual Inspections}

The performance standards of Section 3.0 require that the equipment and structure pass a visual inspection. Decontamination of the dismantled equipment continued until each passed visual inspection per Section 3.1 . The Small Test Cell and the instrumented pressure vessel from the Large Test Cell passed the 'debris rule' visual inspection per Section 3.2. The four rooms (the Exhaust Fan Room, the Small Fire Room, the Large Fire Room, and the Sodium Handling Room) were washed down until they passed visual inspection per 
Section 3.1. The gravel scrubber was dismantled with the equipment portion being decontaminated until it passed visual inspection per Section 3.3 and Section 3.1. The closure activities successfully decontaminated the equipment and structures of the 105-DR LSFF.

If a piece of equipment did not pass inspection or, for some reason, decontamination was not possible, then that piece of equipment was placed in the satellite drum to be managed as a dangerous waste. Only a small volume of equipment failed and none of the larger pieces failed.

\subsubsection{Presence of Calcium Carbonate after Meeting the Visual Standard}

The final wash down of the Exhaust Fan Room was completed in late February 1996. At this time the walls, floor, and ceiling of the Exhaust Fan Room meet the cleanup performance standard of a visually clean surface. About two weeks later (mid-March 1996), a white powder had formed on the walls and ceiling. At that time, it was not known if this white powder was sodium carbonate or if it was some other material.

An informal consultation with Ecology was held on March 26, 1996. This discussion identified one possible source of the white powder as calcium carbonate leaching out of the concrete. It was decide to used a field characterization test to determine if the white powder contained sodium, calcium, or both.

The field characterization testing was conducted on March 29, 1996. The test resulted in a positive result for the presence of calcium. Sodium was not detected. The test report is included as Appendix E.

Based on the results of the field tests, the white powder is not the sodium carbonate dangerous waste residue but calcium carbonate. Calcium carbonate is not one of the constituents of concern. No additional decontamination is required.

\subsubsection{Materials Made Available for Recycle or Reuses}

The closure activities produced over 62 tonnes $/ 62,042$ kilograms $(\mathrm{kg})$ (68 tons/136,799 pounds [1bs]) of material for recycling and reuse. This material can be broken down into the following categories:

1. Scrap stainless steel

2. Miscellaneous scrap steel

3. Recyclable equipment/hardware

4. Mixed scrap stainless steel, scrap steel, and equipment

5. Scrap copper (mainly wire)

6. Reusable scrubber grave]

\section{Total}

$$
\begin{aligned}
& 12,825 \mathrm{~kg}(28,280 \mathrm{Tbs}) \\
& 26,898 \mathrm{~kg} \text { ( } 59,309 \text { lbs) } \\
& 1,710 \mathrm{~kg}(3,770 \text { 1bs) } \\
& 6,975 \mathrm{~kg} \text { ( } 15,380 \text { lbs) } \\
& 934 \mathrm{~kg}(2,060 \mathrm{lbs}) \\
& 12,700 \mathrm{~kg} \text { ( 28,000 1bs) } \\
& 62,042 \mathrm{~kg}(136,799 \text { Jbs })
\end{aligned}
$$


1 The scrap metals and recyclable equipment/hardware have been sent offsite for 2 recycling. The gravel was used onsite for surfacing a parking area at the 3 105-DR Reactor Building.

\subsubsection{Addressing Problems Found During Closure Activities}

No significant unexpected problems or findings occurred during the closure activities. No conditions were discovered that were outside of the scope of the closure plan. Examples of problems that were expected but did not occur include: radiological contamination in the ducts to and from the reactor exhaust tunnels and carbonate contamination on the gravel from the gravel scrubber.

of the problems that were expected during equipment disassembly, only one occurred: previously unidentified asbestos insulation was found on the sodium storage tank in the Sodium Handling Room. The asbestos was found during a routine pre-disassembly test of the insulation on the sodium storage tank. The asbestos insulation was removed by an asbestos remediation crew.

The asbestos that contained waste was either disposed of through the onsite Asbestos Conversion Project or disposed of at the Pasco Landfil1 (offsite).

One minor unexpected problem was that lead paint caused a safety concern when using a cutting torch. Before disassembly of the Large Test Cell, an analysis of the paint on the inside surface of the cell tested positive for lead. The concentration of lead was not high enough to result in a dangerous waste designation under WAC 173-303. However, it was a potential safety concern when using a cutting torch on the painted steel panels. Additional safety equipment (e.g., a mask and additional protective clothing) was required during the cutting operation.

The need to safely isolate the electrical systems used in the 105-DR LSFF required the removal of much more electrical conduit than expected. While this did not directly affect the closure activities, it did increase the cost. The primary driver for removal was the requirement to safely remove and isolate the electrical systems that entered into the four rooms in the 105-DR LSFF.

\subsubsection{Waste Management}

Use of satellite collection areas for the waste residues was effective. The satellites were moved around so they were located next to the current work areas. Use of the less-than-90-day storage pad allowed for the drums to be stored pending an analysis of their contents for disposal purposes. Some of 


$$
\text { WHC-SD-EN-EV-034, ReV. } 1
$$

1 the carbonate-containing drums did designate as dangerous waste because of the presence of lead and chromium. It is believed that the sources are lead paint and stainless steel, respectively. Lead paint and stainless steel exist extensively in the 105-DR Reactor Building and the components of the 105-DR LSFF.

\subsubsection{Cracks in the Floors and Walls}

During implementation of the closure activities, some cracks were noted in the sump and on the floor of the Exhaust Fan Room and on the floor of the Small Fire Room. There were two concerns about cracks in or near the floor: The first was that the cracks may have allowed carbonate to penetrate to the soil during past operations of the 105-DR LSFF. The second was that the cracks could allow liquid decontamination residue to penetrate to the soil during the closure activities. After being examined, none of the cracks were considered large enough to be a concern. This was a subjective judgement since there were no rigid criteria for cracks.

As a precaution, some of the cracks in the Exhaust Fan Room floor and sump were sealed. The Exhaust Fan Room was chosen as the staging and decontamination area for the disassembled equipment. Sealing the cracks ensured that the decontamination residues could not penetrate into the cracks. The good housekeeping practices of using the minimum volume of mild acid solution and collecting any free liquid also helped reduce any potential for decontamination residues to penetrate a crack and enter the soil.

Relatively large cracks were noted at some of the joints between the walls, especially in the Exhaust Fan Room and Small Fire Room. These cracks were not concerns because of their location away from the floor and potential pathways to the soil. The general washdown completed in all rooms of the 105-DR LSFF was considered to have adequately removed any carbonate from these cracks.

\subsubsection{Decontamination of the Area 2 Duct Work and Blower}

As noted in the description of Area 2, there is duct work and a blower connecting the upper and lower parts of the reactor exhaust tunnels (Figure 4). This equipment is located physically within the Closure Area 1 Sodium Handling Room. The internal portions of the duct work and blower were heavily coated with carbonate.

Leaving the Area 2 duct work and blower in place was unacceptable because carbonate-contaminated equipment would remain in Closure Area 1 after the clean closure of Area 1. Therefore, the blower and duct work were dismantled and decontaminated. After decontamination, the dismantled duct work and blower met the equipment performance standard specified in Section 3.1 . The penetrations into the reactor exhaust tunnel were then sealed.

51

52 


\subsubsection{Radiological Aspects Related to the Closure Activities}

Before the start of closure activities, Closure Area 1 of the 105-DR LSFF had been radiologically surveyed. Closure Area 1 was found to be uncontaminated. This survey allowed the radiological protection zone to be moved from the entry door on the south side of the building to the door into the 105-DR Reactor Valve Pit Room (Figure 3).

Spot checks and surveys of equipment and personnel were done throughout the closure activities. Extra care was taken when the potential for radiological contamination was suspected. An example is the Area 2 duct work and blower located in the Sodium Handling Room. No radiological contamination was found during the closure activities.

\subsection{CONCLUSIONS}

The closure activities were successful in meeting the requirements for clean closing Closure Area 1, Closure Area 3, and Closure Area 7. The equipment and building structure from Closure Area 1 were decontaminated to meet the performance standards in Sections 3.1 and 3.2. The analys is of the gravel from Closure Area 3 showed that the gravel met the performance standards in Section 3.3. The equipment from closure Area 3 met the performance standards of Section 3.3. The analysis of the soil from Closure Area 7 showed that the soil met the performance standards in Section 3.4. Appendix D contains before and after photographs of the four rooms and of the gravel scrubber.

The Closure Area 2 blower and associated duct work were included as part of the closure activities and were decontaminated successfully to meet the performance standards in Section 3.1. Including the blower and associated duct work allowed the exhaust tunnel to be isolated and removed carbonate contaminated equipment from within the physical boundaries of Closure Area 1.

The closure activities generated over 62 tonnes (68 tons) of material for recycle or reuse. This includes 12.8 tonnes (14 tons) of scrap stainless steel; 26.9 tonnes (29.7 tons) of miscellaneous scrap steel; 0.9 tonnes (1 ton) of scrap copper/copper wire; 1.7 tonnes (1.9 tons) of recyclable equipment; 6.7 tonnes ( 7.7 tons) of mixed scrap stainless steel, scrap steel, and equipment; and 12.7 tonnes (14 tons) of gravel. A total of 3.4 cubic meters ( 4.5 cubic yards) of asbestos waste was recycled into bricks.

In summary, clean closure was achieved for Closure Area 1, Closure Area 3, and Closure Area 7. The partial clean closure goals of the 105-DR Large Sodium Fire Facility Closure Plan (DOE-RL 1995) have been met. Additionally, Closure Area 2 has been reduced to only the reactor exhaust tunnels. 


\subsection{REFERENCES}

\subsection{DOCUMENTS}

DOE-RL, 1994, Hanford Site Background: Part 1, Soil Background for Nonradioactive Analytes, D0E/RL-92-24, Rev. 2, U.S. Department of Energy, Richland Operations Office, Richland, Washington.

DOE-RL, 1995, 105-DR Large Sodium Fire Facility Closure P7an, D0E/RL-90-25, Rev 2, U.S. Department of Energy, Richland Operations Office, Richland, Washington.

Ecology, EPA, and DOE, 1996, Hanford Federal Facility Agreement and Consent Order, 2 vols., Washington State Department of Ecology, U.S. Environmental Protection Agency, and U.S. Department of Energy, Olympia, Washington.

Ecology, 1994, Guidance for Clean Closure of Dangerous Waste Facilities, August 1994, Publication \#94-111, Washington State Department of Ecology, Olympia, Washington.

EPA, 1986, Test Methods for the Evaluation of Solid Waste: Physical/Chemical Methods, SW-846, as amended, U.S. Environmental Protection Agency, Washington, D.C.

WHC, 1988, Environmental Investigations and Site Characterization Manual, WHC-CM-7-7, Westinghouse Hanford Company, Richland, Washington.

WHC, 1995, 105-DR Large Sodium Fire Facility Decontamination, Sampling, and Analysis Plan, WHC-SD-EN-AP-186, Rev. 0, Westinghouse Hanford Company, Richland, Washington.

WHC, 1996, 105-DR Large Sodium Fire Facility Soil Sampling Data Evaluation Report, WHC-SD-EN-TI-307, Rev. 0, Westinghouse Hanford Company, Richland, Washington.

\subsection{CODE OF FEDERAL REGULATIONS}

40 CFR 260, "Hazardous Waste Management System-General," as amended.

40 CFR 261, "Identification and Listing of Hazardous Waste," as amended.

40 CFR 262, "Standards Applicable to Generators of Hazardous Waste," as amended.

40 CFR 263, "Standards Applicable to Transporters of Hazardous Waste,". as amended

40 CFR 264, "Standards for Owners and Operators of Hazardous Waste Treatment, Storage, and Disposal Facilities," as amended. 
WHC-SD-EN-EV-034, Rev. 1

40 CFR 264, Subpart F (Sections 90 through 101), 1992, "Releases from Solid Waste Management Units," as amended.

40 CFR 264, Subpart X (Sections 600 through 603), "Miscellaneous Units," as amended.

40 CFR 265, "Interim Status Standards for Owners and Operators of Hazardous Waste Treatment, Storage, and Disposal Facilities," as amended.

40 CFR 266, "Standards for the Management of Specific Hazardous Wastes and Specific Hazardous Waste Management Facilities," as amended.

40 CFR 267, "Interim Standards for Owners and Operators of New Hazardous Waste Land Disposal Facilities," as amended.

40 CFR 268, "Land Disposal Restrictions," as amended.

40 CFR 270, "EPA Administered Permit Programs: The Hazardous Waste Permit Program," as amended.

\subsection{FEDERAL AND STATE ACTS}

Comprehensive Environmental Response and Liability Act of 1980, as amended, 42 USC 9601 et seq.

Resource Conservation and Recovery Act of 1976, as amended, 42 USC 6901 et seq.

\subsection{REVISED CODE OF WASHINGTON AND WASHINGTON ADMINISTRATIVE CODE}

WAC 173-303, Dangerous Waste Regulations, Washington State Department of Ecology, Olympia, Washington.

WAC 173-340, The Model Toxics Control Act Cleanup Regulation, Washington State Department of Ecology, 01ympia, Washington. 
WHC-SD-EN-EV-034, Rev. 1

1

APPENDIX A

EVALUATION OF THE GRAVEL SAMPLING DATA 
WHC-SD-EN-EV-034, Rev. 1

This page intentionally left blank. 
WHC-SD-EN-EV-034, Rev. 1

\section{CONTENTS}

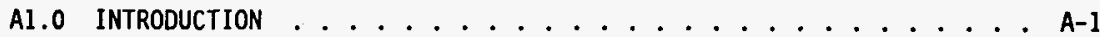
A1.1 SUMMARY OF RESULTS .................. A-1

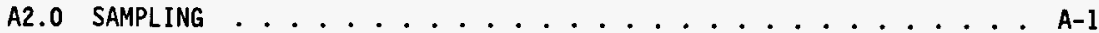
A2.1 SAMPLE LOCATIONS .................... A-2 A2.2 SAMPLE COLLECTION . ............... A-2 A2.2 DEVIATION FROM SAMPLING PLAN ........... A-2 A3.0 PERFORMANCE STANDARDS ................ . . . . . A3.1 METHODOLOGY AND CONSTITUENTS OF CONCERN ......... A-3 A3.2 CORROSIVITY PERFORMANCE STANDARD ........... A-3 A3.3 METALS PERfORMANCE STANDARD ............. A-3

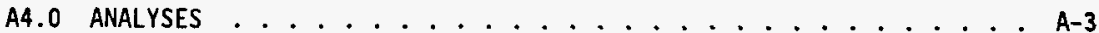

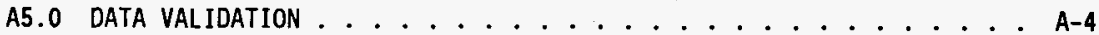
A6.0 DATA EVAlUATION . . . . . . . . . . . . . . A A-4

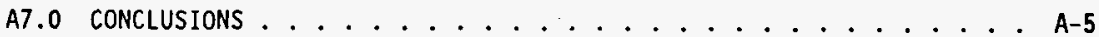

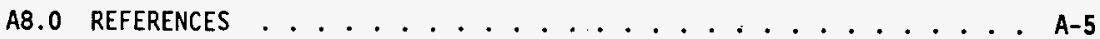

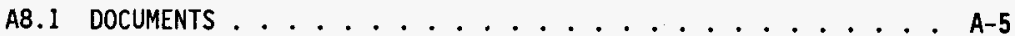
A8.2 CODE OF FEDERAL REGULATIONS ................ A-6

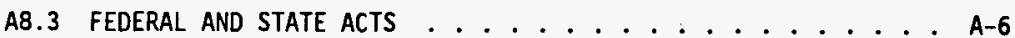
A8.4 REVISED CODE OF WASHINGTON AND WASHINGTON ADMINISTRATIVE CODE ................... A-6 
WHC-SD-EN-EV-034, Rev. 1

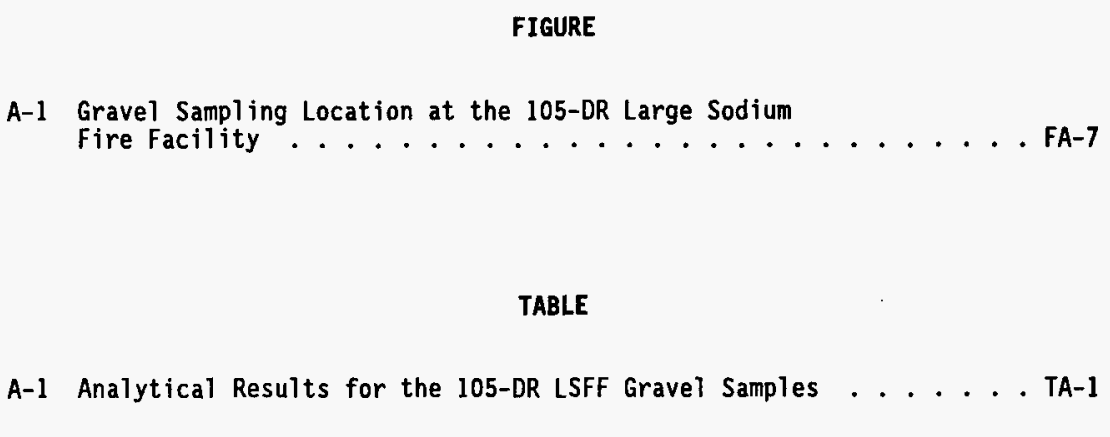

14 A-1 Analytical Results for the 105-DR LSFF Gravel Samples ....... TA-1 
WHC-SD-EN-EV-034, Rev. 1

$\begin{aligned} 1 & \\ 2 & \\ 3 & \\ 4 & \text { CERCLA } \\ 5 & \\ 6 & \text { DQO } \\ 7 & \text { EII } \\ 8 & \text { HEIS } \\ 9 & \text { LSFF } \\ 10 & \text { MTCA } \\ 11 & \text { RCRA } \\ 12 & \text { TCLP } \\ 13 & \text { WAC }\end{aligned}$

\section{LIST OF TERMS}

Comprehensive Environmental Response, Compensation, and Liability Act of 1980 Data Quality Objective Environmental Investigations Instruction Hanford Environmental Information System Large Sodium Fire Facility Model Toxics Control Act Resource Conservation and Recovery Act of 1976 Toxic Characteristics Leaching Procedure Washington Administrative Code 
WHC-SD-EN-EV-034, Rev. 1

This page intentionally left blank. 
WHC-SD-EN-EV-034, Rev. 1

\author{
105-DR LARGE SODIUM FIRE FACILITY \\ SOIL SAMPLING DATA EVALUATION REPORT
}

\title{
A1.0 INTRODUCTION
}

This report summarizes and evaluates the sampling of the gravel from Closure Area 3 and subsequent gravel sample analys is performed in support of the closure of the 105-DR Large Sodium Fire Facility (LSFF). The evaluation will be used to determine if the gravel must be designated as a dangerous waste or if the gravel is sufficiently clean to allow for reuse. The evaluation is based on the validated data included in the data validation packages (105-DR Large Sodium Fire Facility Closure Plan [DOE-RL 1995b]) for the 105-DR LSFF. The results of this evaluation will be used in support of the closure activities at the 105-DR LSFF as described in the DOE/RL-90-25 (105-DR Large Sodium Fire Facility Closure Plan [DOE-RL 1995b]).

This evaluation does not address analytical methodology, nor does it provide raw analytical data or the sampling validation report. The sampling plan is presented in the 105-DR Large Sodium Fire Facility Closure. Plan (DOE-RL 1995b). The sampling plan was discussed and agreed to by all parties during the Data Quality objective (DQO) process meetings held during the first half of 1995. All analytical data were validated according to Data Validation Procedures for Chemical Analysis (WHC 1993). The data validation packages (DOE-RL 1995) already have been transmitted to Washington State Department of Ecology (Ecology).

\section{A1.1 SUMMARY OF RESULTS}

Two samples of gravel from 105-DR LSFF Closure Area 3 were analyzed for Toxic Characteristics Leaching Procedure (TCLP) metals (arsenic, barium, cadmium, chromium, lead, silver, selenium, and mercury) and for corrosivity. The analytical result were evaluated against a set of performance standards based upon the Washington Administrative Code (WAC) Chapter 173-340 "Model Toxics Control Act Cleanup Regulations" and the Hanford Site Background: Part 1, Soil Background for Nonradioactive Analytes (DOE 1994). This evaluation determined that there were no constituents of concern above the specified values. Therefore, the gravel was determined not to be a dangerous waste and that the gravel could be reused.

\section{A2.0 SAMPLING}

Gravel sampling was performed on July 20, 1995, following the sampling and analysis plan described in 105-DR Large Sodium Fire Facility Closure Plan (DOE-RL 1995b) and as modified by the 105-DR Large Sodium Fire Facility Unit Manager Meeting Minutes dated July 18, 1995 (WHC 1995a).

53 
WHC-SD-EN-EV-034, Rev. 1

\section{A2.1 SAMPLE LOCATIONS CLOSURE AREA 3}

Closure Area 3 is south of the 105-DR Reactor Building and adjacent to the 110-DR Stack. A total of two gravel samples were collected at the LSFF as follows: one from the south-west corner of the scrubber and one from the south-east corner. Figure A-1 shows the locations of the gravel samples.

\section{A2.2 SAMPLE COLLECTION}

The two samples collected on July 20, 1995, were assigned Hanford Environmenta1 Information System (HEIS) numbers BOG2F6 and BOG2F7. BOG2F6 was collected at the south-west corner and BOG2F7 was collected at the south-east corner (Figure A-1).

The gravel samples were collected using clean hand tools. Samples were taken using a grain sampler inserted into the gravel bed. Each sample was labeled and placed into a certified clean bottle. All samples were cooled to $4^{\circ} \mathrm{C}$ during storage and transportation to the offsite laboratory. All samples were analyzed within the holding time requirement.

The sampling equipment was cleaned and decontaminated before use at the $1706 \mathrm{KE}$ Laboratory in accordance with Environmental Investigation Instruction (EII) 5.5, "Laboratory Cleaning of Resource Conservation and Recovery Act of 1976 (RCRA)/Comprehensive Environmental Response, Compensation, and Liability Act of 1980 (CERCLA) Sampling Equipment" (WHC 1988). There was no equipment decontamination in the field.

\section{A2.2 DEVIATION FRON SAMPLING PLAN}

There was one deviation from the approved 105-DR Large Sodium Fire Facility Decontamination, Sampling, and Analysis Plan (WHC 1995a). Section 4.0 of the 105-DR Large Sodium Fire Facility Decontamination, Sampling, and Analysis Plan (WHC 1995a) states that "These samples will be obtained as the gravel is removed from the scrubber." The need to designate the gravel before removal prevented the samples from being taken during removal. During the July 18, 1995, meeting with Ecology, the following deviation was agreed upon:

1. Sample the gravel in place

2. Analyze the gravel sample

3. Evaluate the results

4. Dispose of the gravel appropriately.

This agreement is documented in the 105-DR Large Sodium Fire Facility Unit Manager Meeting Minutes dated July 18, 1995 (WHC 1995b). This deviation did not have any adverse affects the results of either the sampling or the closure activities. 


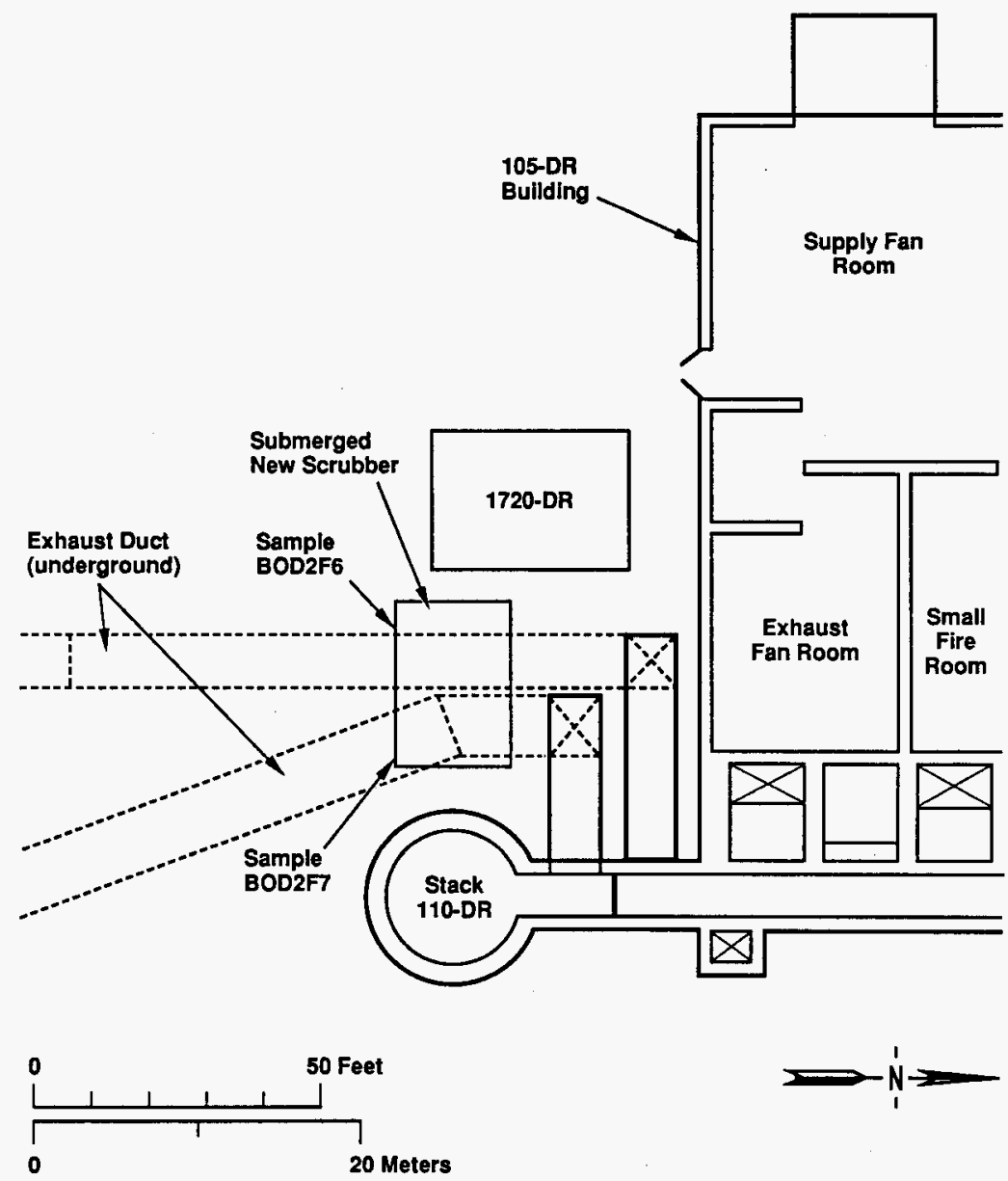

H95 120285.3 105-DR Large Sodium Fire Facility. 


\section{A3.0 PERFORMANCE STANDAROS}

The performance standards for closure of the 105-DR LSFF are defined in Chapter 6 of the closure plan and are based on the requirements of WAC 173-303-610(2)(b). The performance standard for the gravel from the gravel scrubber is designation or non-designation as dangerous waste. If designated, the gravel will be managed as a dangerous waste per the requirements of WAC 173-303. If it does not designate, it will be disposed of as a non-regulated solid waste or reused/recycled. The designation procedure for closure is based on the DQO process meetings held with Ecology during the first half of 1995.

\section{A3.1 METHODOLOGY AND CONSTITUENTS OF CONCERN}

Designation for closure purposes will be based on the Test Methods for the Evaluation of Solid Waste: Physical/Chemical Methods (EPA 1986) TCLP metals analysis and corrosivity $(\mathrm{pH})$ analysis in comparison with the requirements of WAC 173-303-6IO(2)(b). The metals constituents of concern are arsenic, barium, cadmium, chromium, lead, mercury, selenium, and silver. The corrosivity will be measured as $\mathrm{pH}$.

\section{A3.2 CORROSIVITY PERFORMANCE STANDARD}

The corrosivity performance standards for designations purposes are $\mathrm{pH}$ equal to or less than 2 and equal to or greater than 12.5 is considered to be a dangerous waste. A pH value in the range between 2 and 12.5 will not result in designation of the gravel as dangerous waste.

\section{A3.3 METALS PERFORMANCE STANDARD}

The TCLP metals performance standard for designation purposes are the greater of the: sitewide soil background values or Model Toxics Control Act Cleanup Regulations (MTCA). The sitewide soil background concentrations are defined in Hanford Site Background: Part 1, Soil Background for Nonradioactive Analytes (DOE-RL 1994). The MTCA values are defined in the WAC 173-340, Model Toxics Control Act Cleanup Regulations.

A review of the sitewide soil background values against the MTCA values indicated that all of the MTCA values were higher. Therefore, only the MTCA values will be used as the metals performance standards. MTCA Method B values are used for arsenic, barium, cadmium, mercury, selenium, and silver. No MTCA Method $B$ values exist for chromium or lead. The more restrictive Method A values are used instead. These values are presented on Table A-1. 
WHC-SD-EN-EV-034, Rev. 1

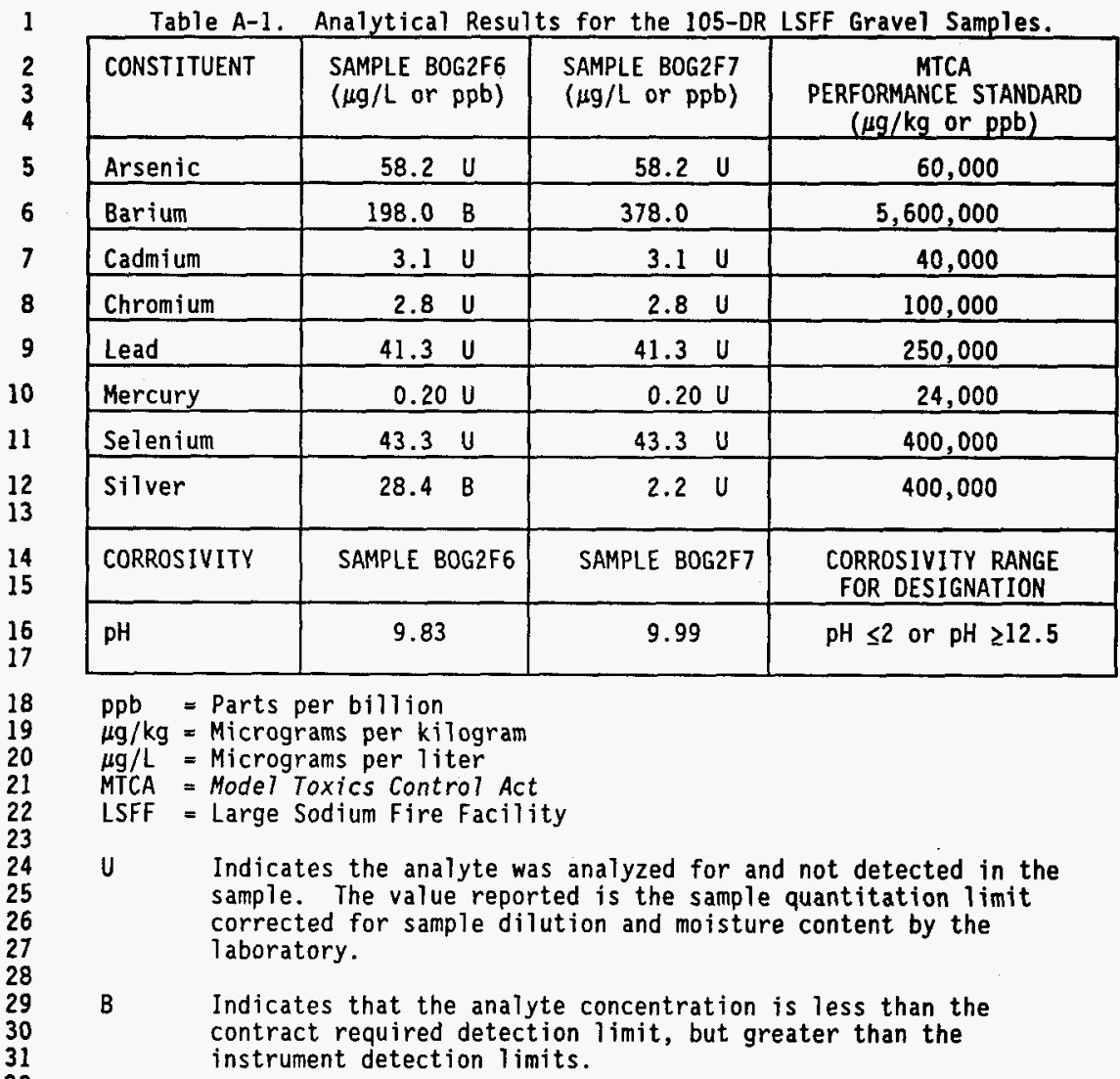

Note: $\mathrm{pH}$ is a unitless measure.

Note: For dilute solutions $\mu \mathrm{g} / \mathrm{L}$ is approximately equal to $\mu \mathrm{g} / \mathrm{kg}$. 


\section{A4.0 ANALYSES}

The corrosivity (pH) analysis used Method 9045 "Solid and Waste $\mathrm{pH}^{\text {" }}$ (EPA 1986). Samples for metals analysis were prepared using Method 1311 "Toxicity Characteristic Leaching Procedure" (EPA 1986). Method 6010, "Inductive1y Coupled Plasma-Atomic Emission Spectroscopy" (EPA 1986) was used to analyze the samples for arsenic, barium, cadmium, chromium, lead, silver, and selenium. Method 7470 "Mercury in Liquid Waste Manual Cold-Vapor Technique" (EPA 1986). Use of Methods 1311, 6010, 7470 and 9045 had been established during the DQO process for the 105-DR LSFF. All samples were sent to Quantera Incorporated in St. Louis, Missouri, for chemical analysis. All analytical data were validated according to Data Validation Procedures for Chemical Analysis (WHC 1993) (refer to Section 5.0). The analytical data are presented in Table A-1.

\section{A5.0 DATA VALIDATION}

Data validation was performed by Los Alamos Technical Associates, Inc., in accordance with Level $D$ as defined in Data Validation Procedures for Chemical Analysis (WHC 1993). Level D validation includes evaluation and qualification of results based on analytical holding times, method blank results, matrix spikes and duplicates, surrogate recoveries, and analytical method blanks.

The criteria and limits for the validation procedures are listed in the source document. Results of the data validators' review of the quality control that was applied in this sampling event were transmitted to the regulators with the validated data packages (DOE-RL 1995c).

The data analytical laboratory assigned the following qualifier and definition to describe the barium and silver data in sample BOG9F6:

$B$ Indicates that the analyte concentration is less than the contract required detection limit, but greater than the instrument detection limits.

The reason for assigning this qualifier to the barium and sodium data is given in the definition of the qualifier.

\section{A6.0 DATA EVALUATION}

The analytical data values for arsenic, barium, cadmium, chromium, lead, mercury, selenium, and silver are summarized and compared to the MTCA-based performance standards in Table $A-1$. One sample (BOG2F9) reported the barium and silver data qualified with a ' $B$ ' by the laboratory. This indicates that 
WHC-SD-EN-EV-034, Rev. 1

1 these values are less than the contract required detection limit but greater

2 than the instrument detection limit.

Only barium and silver were detected in the analysis. The detected concentrations of both barium and silver are well below the MTCA-based performance standards. All other constituents of concern were, if present, in concentrations below the sample quantitation limit. The quantitation limits for arsenic, cadmium, chromium, lead, mercury, and selenium are all well below the MTCA-based performance standards.

The analytical data values for $\mathrm{pH}$ are presented in Table $\mathrm{A}-1$. The $\mathrm{pH}$ values for the gravel samples were between $\mathrm{pH} 2$ and $\mathrm{pH} 12.5$.

Based on the data evaluation, none of the performance standards were exceeded. The gravel does not designate as dangerous waste.

\section{A7.0 CONCLUSIONS}

The analytical results for the 105-DR LSFF scrubber gravel verify that no constituents are present in concentrations that would result in a dangerous waste designation for the gravel. The $\mathrm{pH}$ of the gravel is neither high enough or low enough to be designated as a dangerous waste on that basis. Therefore, the gravel would not designate as a dangerous waste. The scrubber gravel can either be disposed of as a non-regulated solid waste or reused.

\section{A8.0 REFERENCES}

\section{A8.1 DOCUMENTS}

DOE-RL, 1995a, Letter, J. E. Rassmussen, RL, and W. T. Dixon, WHC, to M. N. Jaraysi, Ecology, and J. J. Witczak, Ecology, "Submittal of Validated Data for the 105-DR Large Sodium Fire Facility Sampling (T-1-1)," dated December 13, 1995, 95-PCA-054, U.S. Department of Energy, Richland Operations office, Richland, Washington.

DOE-RL, 1995b, 105-DR Large Sodium Fire Facility Closure Plan, DOE/RL-90-25, Rev. 1, U.S. Department of Energy, Richland Operations Office, Richland, Washington.

DOE-RL, 1995C, Hanford Site Background: Part 1, Soil Background for Nonradioactive Analytes, DOE/RL-92-24, Rev. 3, U.S. Department of Energy, Richland Operations office, Richland, Washington.

EPA, 1986, Test Methods for the Evaluation of Solid Waste: Physical/Chemical Methods, SW-846, as amended, U.S. Environmental Protection Agency, Washington, D.C. 


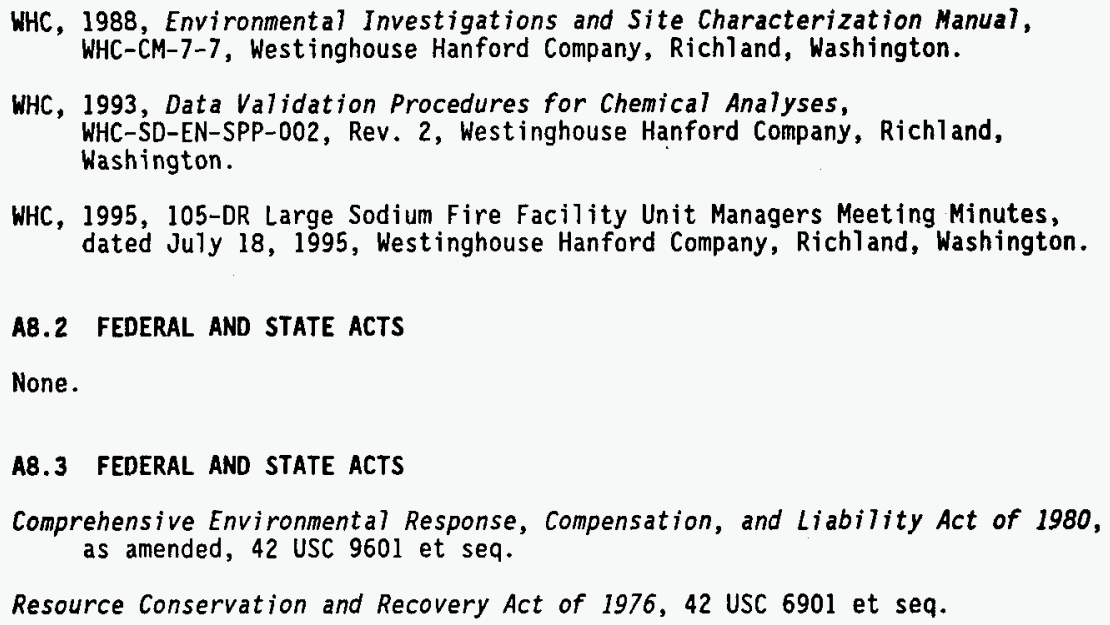

A8.4 REVISED CODE OF WASHINGTON AND WASHINGTON ADMINISTRATIYE CODE

WAC 173-303, "Dangerous Waste Regulations," Washington Administrative Code, as amended.

WAC 173-340, "The Model Toxics Control Act Cleanup Regulations," Washington Administrative Code, as amended. 
WHC-SD-EN-EV-034, Rev. 1

\section{APPENDIX B}

2
3
4

UNIT MANAGERS MEETING MINUTES:

JULY 18, 1995 AND JANUARY 18, 1996 
WHC-SD-EN-EV-034, Rev. 1

This page intentionally left blank. 
WHC-SD-EN-EV-034, Rev. 1

\author{
Meeting Minutes Transmittal - Approved \\ Unit Managers Meeting \\ 105-DR LARGE SODIUI FIRE FACILITY \\ Federal Bldg., Rm 784-B \\ Richland, Washington \\ Meeting Held July 18, 1995 \\ From 2:00 pm to $3: 30 \mathrm{pm}$
}

The undersigned indicate by their signatures that these meeting minutes reflect the actual occurrences of the above dated Unit Managers Meeting.

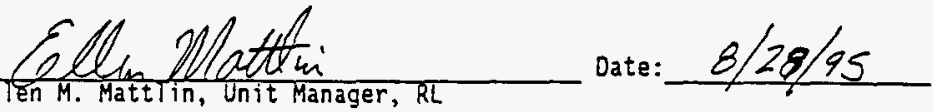

\title{
Not Present
}

Date:

Daniel L. Duncan, RCRA Program Manager, EPA Region 10

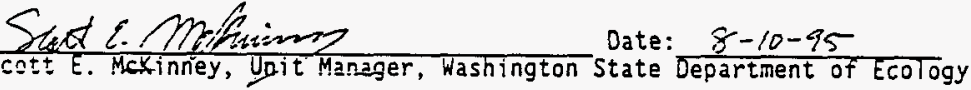

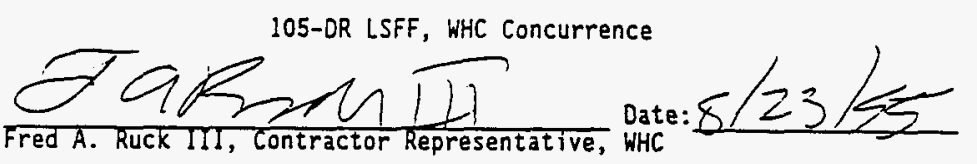

\section{Purpose: Discuss Permitting Process}

Meeting Minutes are attached. The minutes are comprised of the following:

Att achment I - Agenda

At tachment 2 - Summary of Discussion and Commitments/Agreements

Attachment 3 - Attendance list

Attachment 4 - Action Items 
WHC-SD-EN-EV-034, ReV. I

\author{
Attachment 1 \\ Unit Managers Meeting \\ 105-DR LARGE SODIUM FIRE FACILITY \\ Federal Bldg., Rm 784-B \\ Richland, Washington \\ Meeting Held July 18, 1995 \\ From 2:00 pm to $3: 30 \mathrm{pm}$
}

\title{
Agenda
}

1. Approval of Past UMM Minutes

2. Status Action Items

3. Status Closure Activities

- Status of Sampling and Analysis Activities

4. New Business

5. Set Next Meeting Date 
WHC-SD-EN-EV-034, ReV. 1

\author{
Attachment 2 \\ Unit Managers Meeting \\ 105-DR LARGE SODIUM FIRE FACILITY \\ Federal Bldg., Rm 784-B \\ Richiand, Wastington \\ Meeting Heid july 18, 1995 \\ From 2:00 pm to $3: 30 \mathrm{pm}$
}

Summary of Discussion and Commitments/Agreements

1. Approval of Past UMM Minutes

Unit Managers Meeting minutes for May 24, 1995, have been approved and are awaiting signatures. The June 20, 1995, minutes are out for review.

2. Status Action Items

No open action items.

3. Status Closure Activities

-Status of Sampling and Analysis Activities

WHC (ZC Knaus) stated that sampling activities are progressing well. so il samples were taken on the meriting of Juiy 18, 1995. Two soil samples for closure determination were obtained, as well as three authoritative samples at the WHC Field Team Leader's (RC Roos)

discretion. He felt that the three authoritative samples would add to the information gained from the other soil locations.

It had been planned to sample the gravel scrubber on this day as well. A portable saw was to be used to gain access into the gravel scrubber. However; the walls of the scrubber were too thick for the portable saw, so the work was stopped. It was decided to use a welder to cut the steel walls of the scrubber. Hork was planned to continue on July 20, 1995, to allow for time to rewrite the Radiation Work Permit to include a welder and also to organize all extra equipment necessary to complete the welding job.

Other closure activities: the procurement process for ordering equipment necessary to remove carbonates is continuing. Work on carbonate removal will begin after the arrival of this equipment, which is are anticipated to begin sometime in August or September, 1995. Sandblasting of the vessel that was used to burn the 1 ithiumlead alloy is scheduled to begin the first or second week of September, 1995.

4. New Business

Deviations from the Sampling and Analysis Plan

ZC Knaus reported that there would be a deviation from the activities discussed in Section 4.0, Waste Sampling and Removal. The text of the 
Sampling and Analysis Plan states that the gravel will be sampled as it is renoved from the scrubber. A different approach will be taken as follows: 1.) the gravel will be sampled in place, 2.) analyze gravel samples, 3.) evaluate results, 4.) dispose of gravel appropriately. Ecology (SE McKinney) did not have any problems with this deviation from the Sampiing and Analysis Plan.

\section{Set Next Meeting Date}

The next UMM will be held via video conference on August 10, 1995 , Federal Bidg., Richland, Washington. 
WHC-SD-EN-EV-034, Rev. 1

\section{Attachment 3}

\section{Unit Managers Meeting \\ 105-DR LARGE SODIUM FIRE FACILITY \\ Federal Bldg., Rm 784-B \\ Richland, Washington}

Meeting Held July 18, 1995

From 2:00 pm to $3: 30 \mathrm{pm}$

\section{Attendance List}

\begin{tabular}{|c|c|c|}
\hline Name & Organization & Phone : \\
\hline Kathy Knx & WHC & $372-3596$ \\
\hline TOAN K B BRTE & GSSC & $372-2008$ \\
\hline Eachery Knaus & 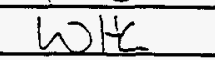 & $322-1.597$ \\
\hline ELLEN MATTLIN & DOE-RL & $376-2385$ \\
\hline PLil M.llere & WHC & $376-0441$ \\
\hline Jagin Adler & $u+1 c$ & 376.7513 \\
\hline Dowa Chapin & DOE-RL-TPD & 373.9396 \\
\hline Solt Mchima Videornui. & Ecolory & $206-4 n 7-7146$ \\
\hline 1 & 11 & \\
\hline & & \\
\hline & & \\
\hline & & \\
\hline & & \\
\hline & & \\
\hline & & \\
\hline & & \\
\hline & & \\
\hline & & \\
\hline
\end{tabular}




$$
\text { WHC-SD-EN-EV-034, Rev. } 1
$$

\author{
Attachment 4 \\ Unit Managers Meeting \\ 105-DR LARGE SODIUM FIRE FACILITY \\ Federal Bldg., Rm 784-B \\ Richland, Washington \\ Meeting Held July 18, 1995 \\ From 2:00 pm to 3:30 pm
}

\title{
Action Items
}

Action Item \#

Description

no open action items 


\author{
Meeting Minutes Transmittal - Approved \\ Project Managers Mesting \\ 105-DR LARGE SODIUM FIRE FACILITY \\ Federal Building., Rm 784-B \\ Richland, Washington \\ Meeting Held February 29, 1996 \\ From 2:00 pm to 3:00 pm \\ Via video teleconference
}

The undersigned indicate by their signatures that thesa meeting minutes refilect the actual occurrences of the above dated project Managers Meeting.
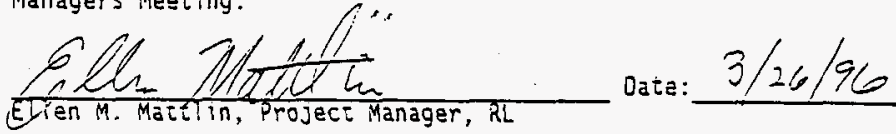

\title{
Not Present
}

RCRA Program Manager, EPA Region IO

Date: Scapd E. Matium Date: $\frac{3-2 c-96}{\text { Scott E. MCXinney, Proyeci Manager, Wasnington State Department of }}$
Ecology

105-DR LSFF, WHC Concurrence

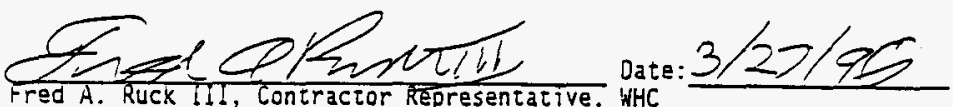

\section{Purpose: Oiscuss Permitting Process}

Meeting Minutes are attached. The minutes are comprised of the following: Attachment 1 - Agenda

Attachment 2 - Summary of Discussion and Commitments/Agresments

Attachment 3 - Attendance List

Attachment 4 - Action Item 
WHC-SD-EN-EY-034, Rev. 1

Attachment I

Project Managers Meeting

105-DR LARGE SODIUM FIRE FACILITY

Federal Building., $R m$ 784-B

Richland, Washington

Meeting Held January 18, 1996

From 8:00 am to 9:00 am

Via video teleconference

\section{Agenda}

1. Approval of Past UMM Minutes

2. Status Action Items

- None

3. Status Closure Activities

- Status of Sampling and Analysis Activities

- Status of Decontamination Activities

- Change in Decontamination Method

4. New Business

5. Summary of Actions/Decisions

6. Set Next Meeting Date 
WHC-SD-EN-EV-034, ReV, I

\author{
Attachment 2 \\ Project Managers Meeting \\ 105-DR LARGE SODIUM FIRE FACILITY \\ Federal Building., Rm 784-B \\ Richland, Washington \\ Meeting Held January 18, 1996 \\ From 8:00 am to 9:00 am \\ Via video teleconference
}

Summary of Discussion and Commitments/Agreements

1. Approval of Past UMM Minutes

Project Managers Meeting minutes for September 12, 1995, October 12 , 1995, and November 30, 1995 have been reviewed, approved, and issued.

As previously agreed, there was no project manager's meetings during December 1995.

2. Status Action Items

None.

3. Status of Sampling and Analysis Activities

- Status of Sampling and Analysis Activities

WHC (J. G. Adler) stated that the validated data had been transmitted to Ecology. Ecology (S. E. Mckinney) stated that the data had been received. WHC also stated that the data evaluation report for the soil sampling was in the final stages of preparation and should be transmitted to Ecology in late January or early February

- Status of Decontamination Activities

WHC (J. G. Adler) stated that the decontamination activities are moving along very smoothly. The sodium storage tank in the Sodium Handling Room has had the asbestos containing insulation removed. About 45 cubic yards $\left(y^{3}\right)$ of asbestos containing insulation will be recycled into glass bricks. About $10 \mathrm{yd}^{3}$ will be disposed of in Hanford's landfill. Ecology asked how the recycling process works. WHC ( $P$. C. Miller) reported that it is a portable system mounted in a semi-traiter. The material is wetted with a borax-soda mixture, shredded by machine, melted in a high temperature oven (about 2000 degree F), and then quenched. The exhaust from the oven is scrubbed using sodium hydroxide to remove organics from the exhaust. The final product is a non-hazardous form of asbestos that can be used beneficially.

WHC (J. G. Adler) continued: Two semi-trailer loads of scrap metal, about 10 tons worth, have been shipped off-site for recycling. At least one additional semi-traijeg load of scrap metal is expected. 
The duct work in the Sodium Handling Room has been removed. No problems occurred and no radiological contamination was found. The steel chamber in the Large Fire Room will be cut-up. This is required in order to access the top and the area between the east wall and the steel chamber for decontamination. Currently, the remaining out-ofservice electrical utilities are being removed from the Large fire Room.

Work has started on the duct work between the gravel scrubber and the exhaust stacks. Work will start a the scrubber and work toward the stacks. There is a potential for radiological contamination in this area. The remaining work at 105-OR is: Dismantle the steel chamber and complete clean-out of the Large Fire Room; Dismantie the duct work between the stack and the scrubber; remove the gravel from the scrubber; and address the scrubber itself.

Ecology asked what will happen to the gravel in the scrubber. WHC (P. $C$. Milier) responded that, if it designates as a non-dangerous waste, it can be used for fill. Ecology also asked what was the expected. completion date for the decontamination. WHC (J. G. Adler, P. C. Mitier, and F. A. Ruck) responded that the March 1996 completion date still held. More work has been needed than was expected but the work has also proceeded faster than was expected. It is possible that the decontamination activities will be completed sooner.

- Change in Decontamination Method

WHC (J. G. Adler) reported that the change in the decontamination method for the two potentially lead contaminated vessels needs to be documented. The 105-DR Large Sodium Fire Facility Decontamination, Sampling, and Analysis P7an, WHC-SD-EN-AP-186, specifically identified that wet sandblasting would be used. As discussed at previous meeting, high pressure $(40,000$ psi) water blasting was used instead. Both technologies are on the Debris Rule (40 CFR 268) list of approved treatment technologies and both have the same performance standard. WHC asked if Ecology acknowledged the change and agree that the water blast was equivalent to the wet sandbiasting. Ecology (S. E. Mckinney) acknowledged the change and agreed that water blasting was an appropriate technology.

4. New Business

None.

5. Summary of Actions/Decisions

1. Closure activities to be completed around March 1996.

2. The replacement of the wet sandblasting by high pressure water blasting was acknowledged and accepted by the $\mathrm{RL}$ and WHC.

No numbered action items were assigned at this meeting. 


\section{WHC-SD-EN-EV-034, ReV. 1}

6. Set Next Meeting Date

Instead, the next UMM will be held via video conference on February 29 , 1996, at the Federal Building, Richland, Washington. 
WHC-SD-EN-EV-034, Rev. 1

\section{Attachment 3}

\section{5-DR LARGE SODIUM FIRE FACILITY \\ Unit Managers Meeting \\ Federal Building, Room 784-B \\ Richland, Washington}

January 18, 1996

8:00 a.m. - 9:00 a.m.

\section{Attendance List}

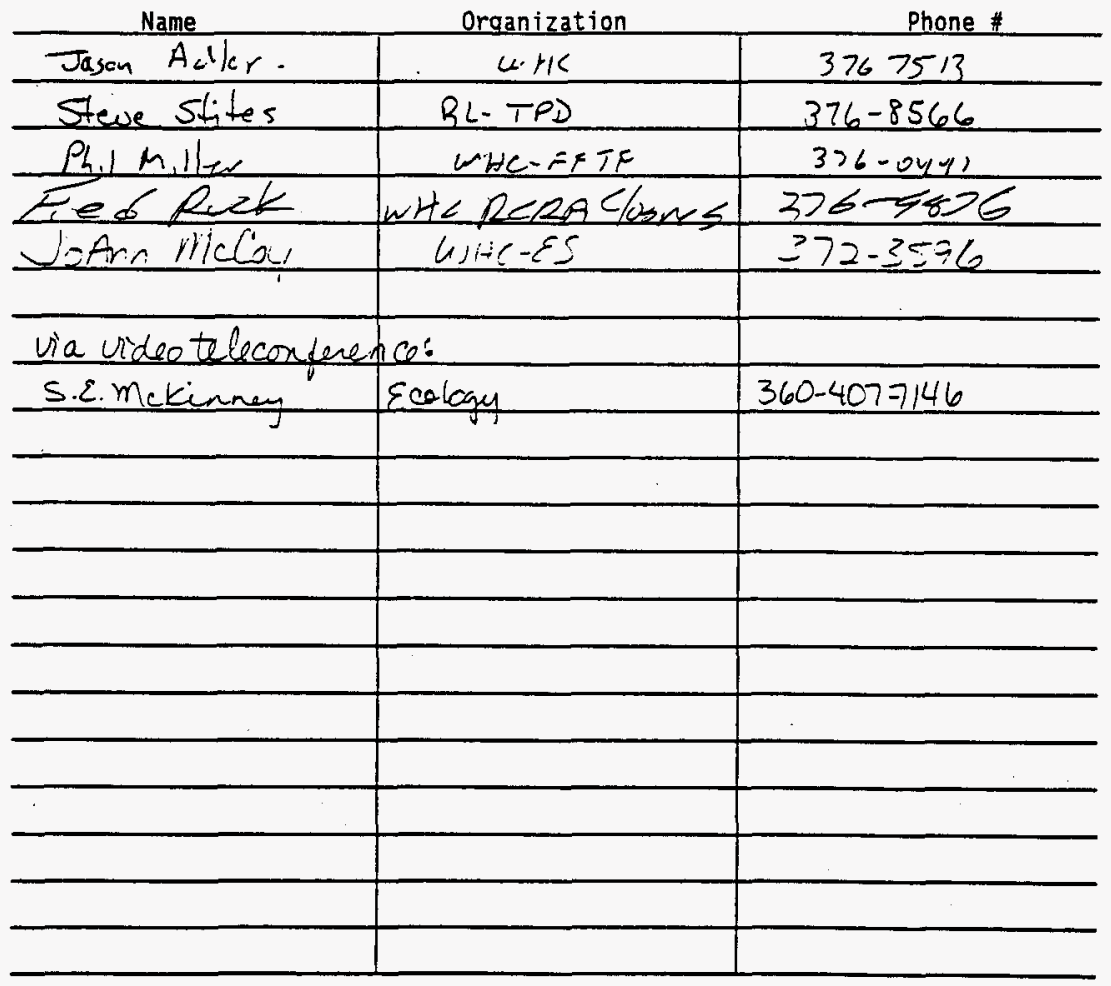


WHC-SD-EN-EV-034, Rev. 1

APPENDIX C

VERIFICATION OF COMPLETION 
WHC-SD-EN-EV-034, Rev. 1

1

2

3

4

This page intentionally left blank. 


\section{VERIFICATION OF COMPLETION}

A. Treatment/Storage/Disposal Unit: 105-DR Large Sodium Fire Facility

Component(s): $\quad$ Small Fire Vessel; Vessel from the Large Test Cell

B. Decontamination Method': High Presure Water Soray

Method Parameter(s) (as applicable):

[ ]. Temperature

$[x]$. Pressure

(e.g., shot, grit, beads)

[ $]$. Residence time

$[x]$. Surfactant $(s)$

$[x]$. Detergents

[ ]. Grinding/striking media (e.g., wheels, piston heads)

[ ]. Depth of surface layer removal

C. The decontamination of the above identified component(s) has been completed using the specified treatment method.

\begin{tabular}{l}
40,000 psi \\
\hline none used \\
\hline none used \\
\hline
\end{tabular}

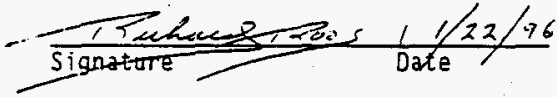

D. The above identified component(s) have undergone decontamination in accordance with Table 1, Alternative Treatment Standards for Hazardous Debris, 40 CFR 268.45, and have achieved a clean debris surface as verified by visual inspection.

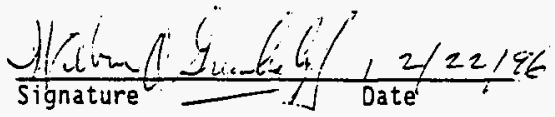

Notes:

1. Physical or chemical extraction method from Table 1. Alternative Treatment Standards for Hazardous Debris, 40 CFR 268.45.

2. Clean debris surface: Surface, when viewed without magnification, is free of all visible contaminated soil and dangerous waste, except allowed as follows:

a) Residual staining from soil and waste consisting of light shadows, stight streaks and minor

discolorstion

b) Soil and wate in cracks, erevices and pits limited to no more that $5 \%$ of each square inch of surface area 
WHC-SD-EN-EV-034; Rev. 1

This page intentionally left blank. 
WHC-SD-EN-EV-034, ReV. 1

APPENDIX D

BEFORE AND AFTER PHOTOGRAPHS 
WHC-SD-EN-EV-034, Rev. 1

This page intentionally left blank. 
WHC-SD-EN-EV-034, Rev. I

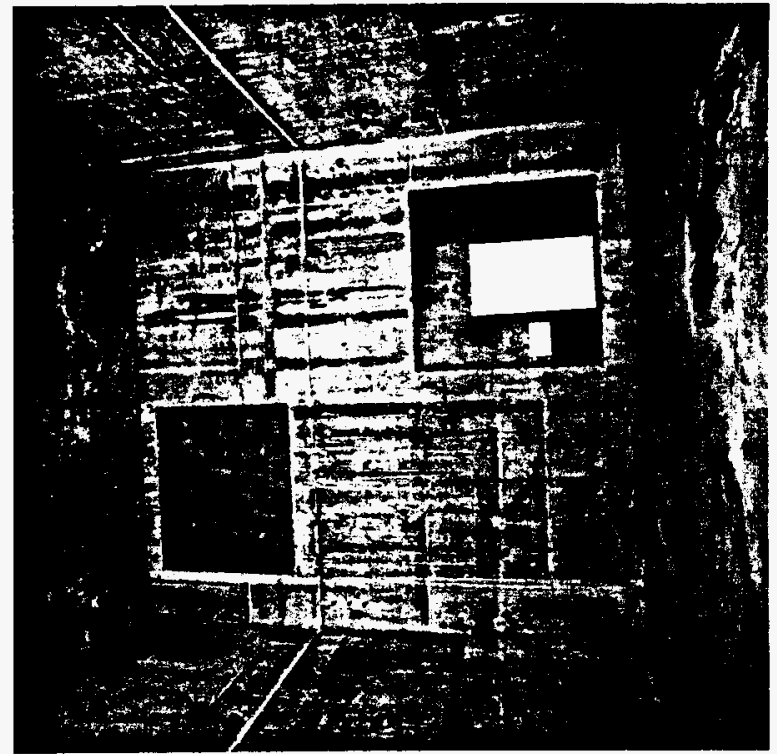

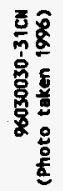

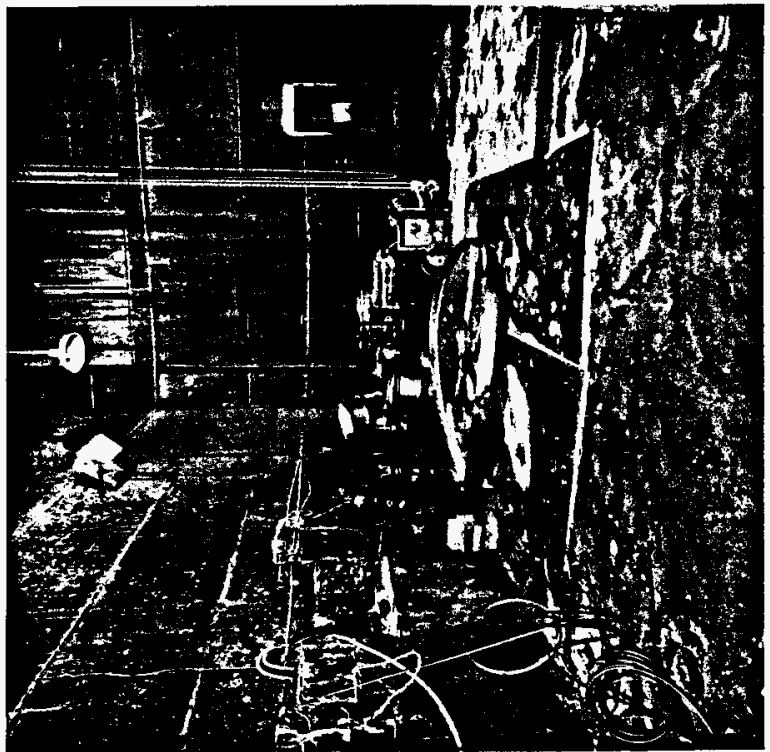

$\frac{0}{5}$

틍

응

ह5

ᄂ

芯=

․․

岳品

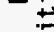

$\because>$

$+7$

$\because \frac{1}{2}$

‘

논

원

는

E4

훌

톨 응

㟧

혼응

옹 혼

눈

낭하

음

गे

苟 


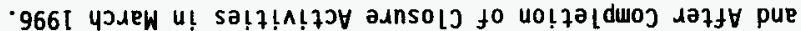

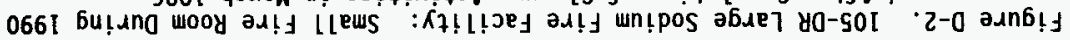

(966t vayez 0704d)

N265-05005096
(066) (40)187 0704d)

Nว\ट-6£60£006
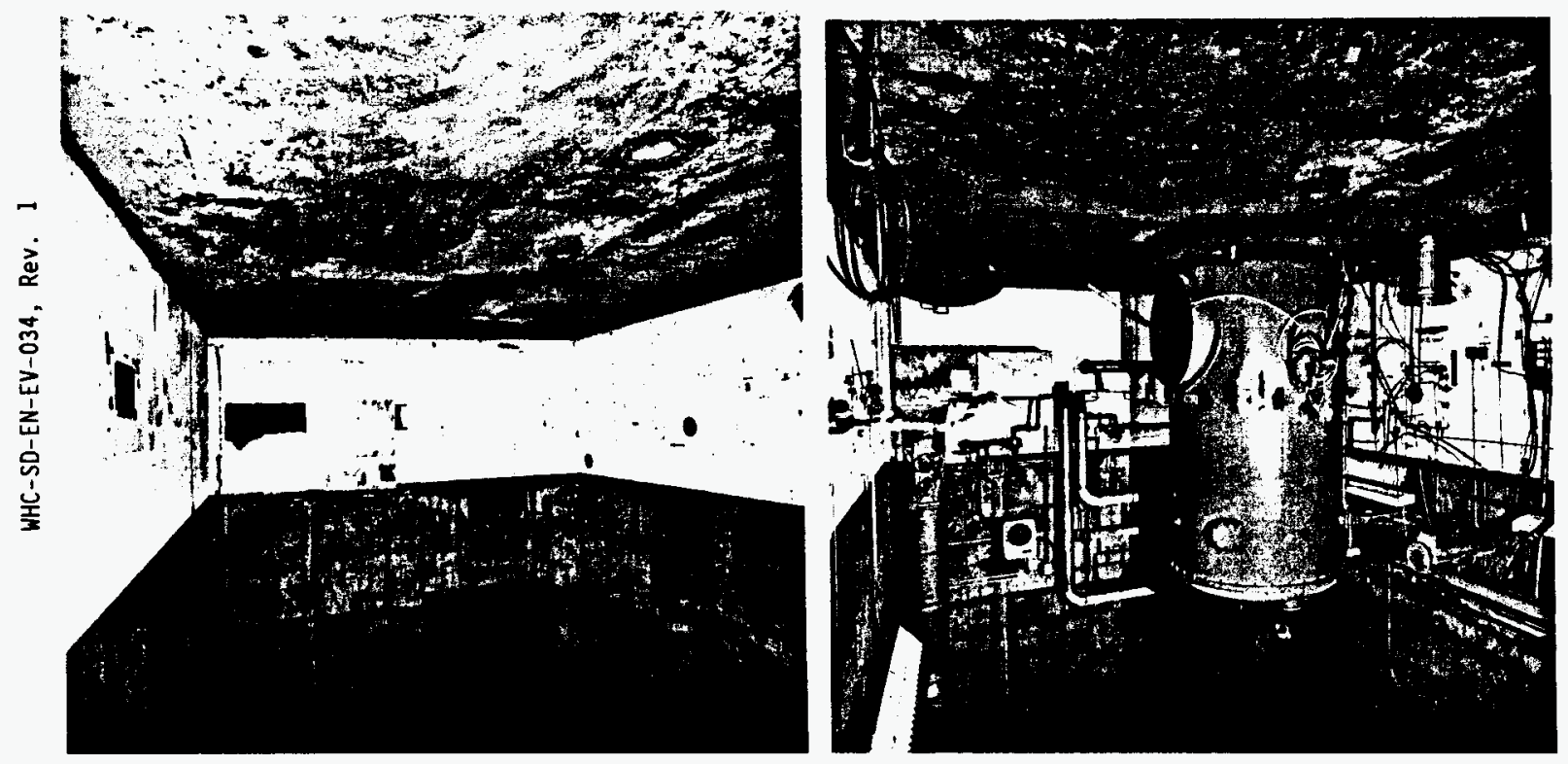


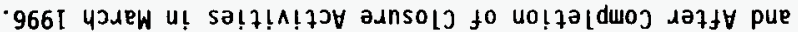

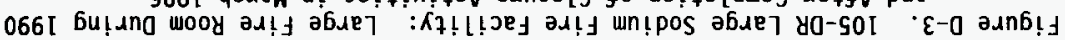

( 9661 woxed ojoud)

N202-05005096

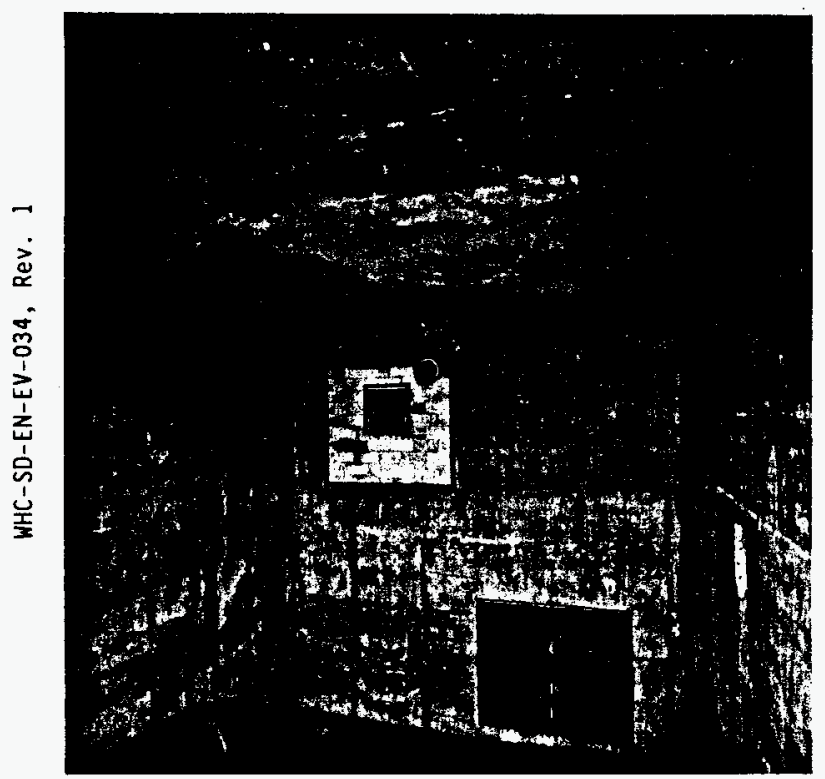

(0661 Vayed 0204d)

NOEZ-6£60£006

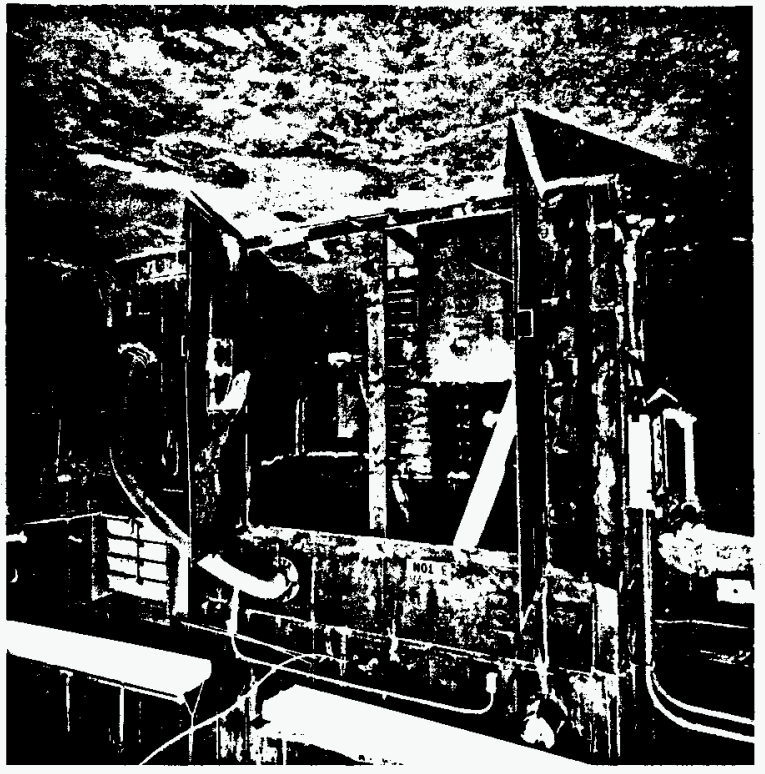




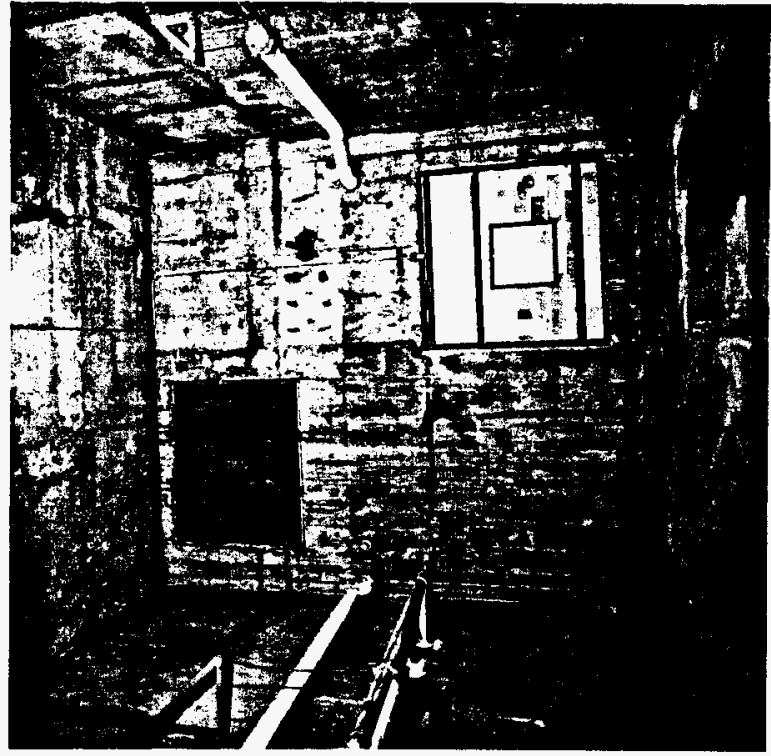

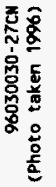

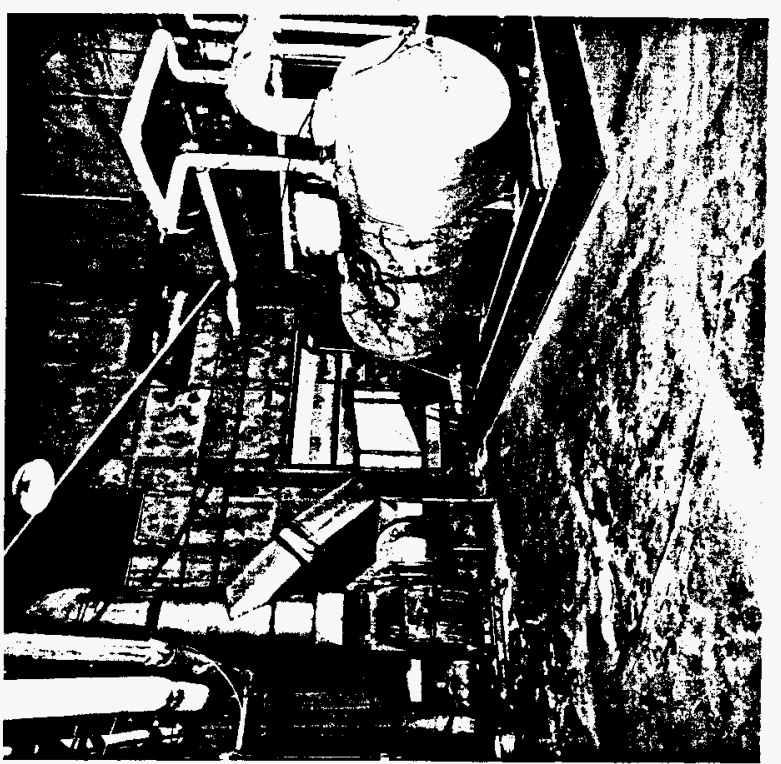

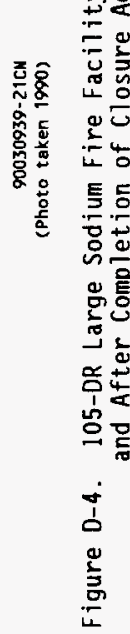




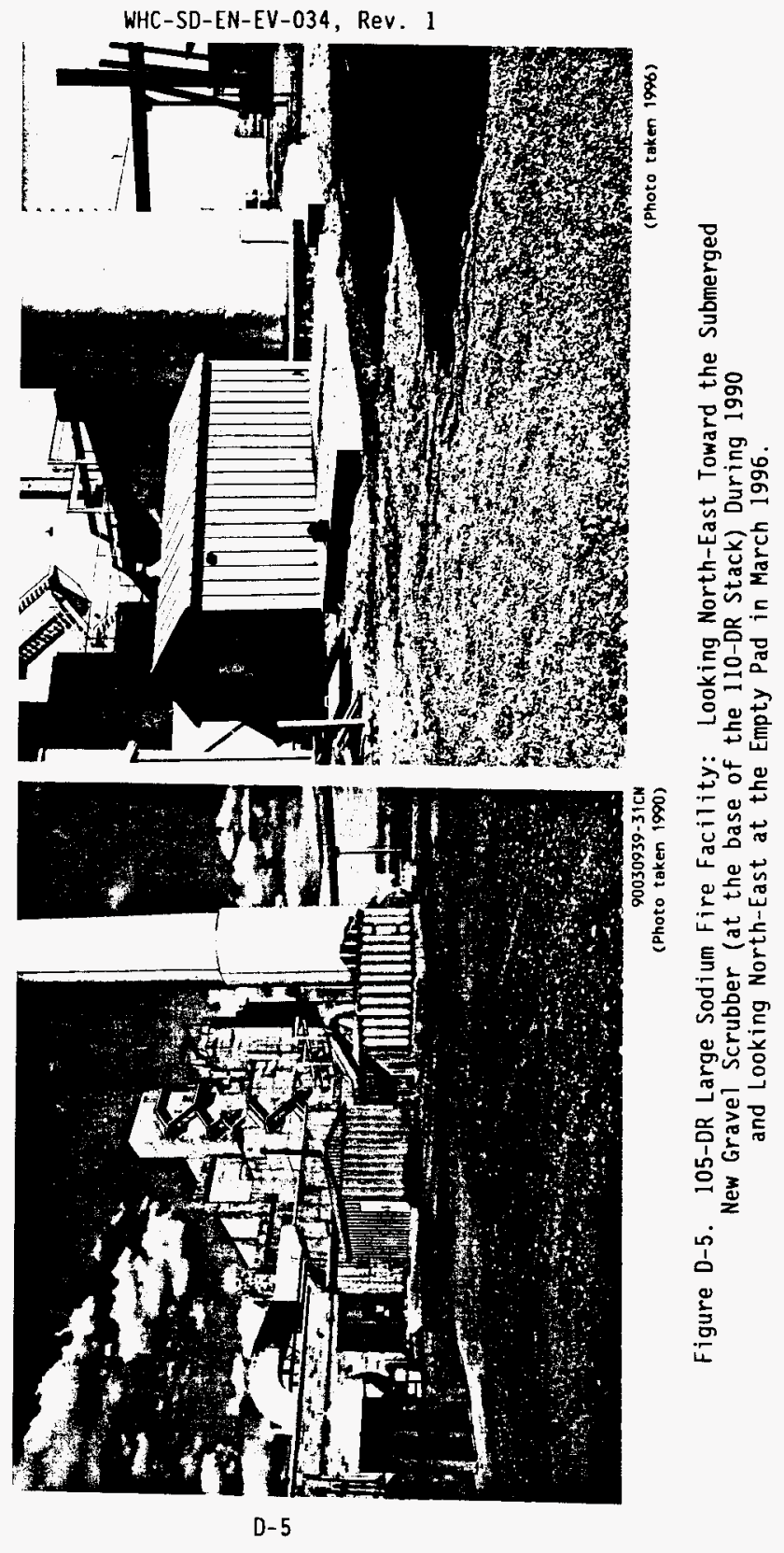


WHC-SD-EN-EV-034, Rev. 1

FIELD CHARACTERIZATION REPORT 
WHC-SD-EN-EV-034, Rev. 1

This page intentionally left blank. 
Westinghouse WHC-SD-EN-EV-034, Rev. 1

From: Special Analytical Studies

Phone: $373-4771$ 53-90

Date: April 1, 1996

Subject: FT6039 - 1050R Facility

To:

J. G. Adler
cc: D.j. Smith
cc: D. J. Smith

s3-90 gl

Attached is the analytical report in support of this project.

If you have any questions regarding analysis, please contact either Mr. Don Smith at 373-2482 or Ms. Joy Smith at

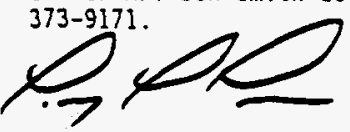

L. L. Lockrem

Manager

sir

Attachment 


\section{FAST PROJECT FT6039 105DR Facility}

\section{Project Sampling and Analytical Screening Case Narrative}

On March 29, 1996, Field Analytical Services Team (FAST) personnel collected a sample from the 1050R facility walls. A stainless steel scoopula was used to scrape a white carbonate material from the facility wall. The sample was placed into a certified clean boroscilicate glass vial for testing at the facility. Sampling and testing information is contained in WHC-N-1025-2.

The sample was tested for the presence of calcium and or sodium. The Hazardous Chemical Testing Kit was used for analytical screening of the sample. Initiaily, a calcium test was performed by adding ammonium oxalate to a solution of the sample mixed with water. The addition of ammonium oxalate resulted in a white precipitate which indicates the presence of calcium. To confirm this a metals analysis test was performed. The flame test consists of heating a flame wire loop and then coating it in the sample solution and placing it in a torch flame. The flame colors give indication of metals which may be present. The flame color was observed through a green glass, displaying an orange color which indicates calcium and through a cobalt blue glass, displaying a yellow color which also indicated the presence of calcium. If sodium was present in this sample, the sodium salts would have re-solidified as crystals on the flame wire. This did not occur.

Based on the testing performed, the material on the 105DR facility wall is a calcium carbonate. 
WHC-SD-EN-EV-034, Rev. 1

1

2

3

4

5

6

7

8

9

10

11

12

13

14

15

16

17

18

19

20

21

22

23

24

25

26

27

28

29

30

\section{DISTRIBUTION}

Number of copies

\section{ONSIIE}

2

U.S. Department of Energy, RichTand Operations office

E. M. Mattli in

A5-15

D. H. Chapin

N2-36

1

GSSC

S. K. Johansen

B1-42

10

Westinghouse Hanford Company

J. G. Adler

W. 0. Greenhalgh

P. C. Miller

S. M. Price

R. C. Roos

F. A. Ruck III

K. J. Young

Central Files

Document Processing Center
H6-23

L5-31

N2-57

H6-23

53-24

H6-23

S3-27

A3-88

A3-94 
WHC-SD-EN-EV-034, Rev. 1

This page intentionally left blank.

Distr-2 